University of Louisville

ThinkIR: The University of Louisville's Institutional Repository

Electronic Theses and Dissertations

$5-2020$

\title{
We've got the 'hots' for changing teacher misconceptions of learning styles: a mixed-methods approach.
}

\author{
Allison Paige Fowler \\ University of Louisville
}

Follow this and additional works at: https://ir.library.louisville.edu/etd

Part of the Educational Psychology Commons

\section{Recommended Citation}

Fowler, Allison Paige, "We've got the 'hots' for changing teacher misconceptions of learning styles: a mixed-methods approach." (2020). Electronic Theses and Dissertations. Paper 3364.

https://doi.org/10.18297/etd/3364

This Doctoral Dissertation is brought to you for free and open access by ThinkIR: The University of Louisville's Institutional Repository. It has been accepted for inclusion in Electronic Theses and Dissertations by an authorized administrator of ThinkIR: The University of Louisville's Institutional Repository. This title appears here courtesy of the author, who has retained all other copyrights. For more information, please contact thinkir@louisville.edu. 


\title{
WE'VE GOT THE 'HOTS' FOR CHANGING TEACHER MISCONCEPTIONS OF LEARNING STYLES: \\ A MIXED-METHODS APPROACH
}

\author{
By \\ Allison Paige Fowler \\ B.A., University of Kentucky, 2016 \\ A Dissertation Submitted to the Faculty of the \\ College of Education and Human Development of the University of Louisville \\ in Partial Fulfillment of the Requirements \\ for the Degree of \\ Doctor of Philosophy \\ In Counseling and Personnel Services \\ Department of \\ Educational Psychology, Measurement, \& Evaluation \\ University of Louisville
}

May 2020 

WE'VE GOT THE 'HOTS' FOR CHANGING TEACHER MISCONCEPTIONS OF

LEARNING STYLES:

A MIXED-METHODS APPROACH

\section{By}

Allison Paige Fowler

B.A., University of Kentucky, 2016

A Dissertation Approved on

April 24, 2020

By the following Dissertation Committee:

Dr. Jeff Valentine

Dr. Kate Snyder

Dr. Jill Adelson

Dr. Meera Alagaraja 


\section{DEDICATION}

This dissertation is dedicated to my husband, Nathaniel, who is my constant. From the moment I decided to apply to graduate school, Nathaniel has stood alongside me, cheering me on and pushing me forward.

I count myself both lucky and proud to take on life and all of its uncertainties with him. 


\section{ACKNOWLEDGEMENTS}

"It's a lesson that I've learned over and over again and it bears repeating. No one achieves anything alone. I owe this victory, all of it, to my friends and supporters"

-Leslie Knope

Firstly, I want to express my unending thankfulness for my committee. I am grateful to Jeff Valentine, whose office door has always been open to me and my many questions. I owe nearly all of my understanding of quantitative methodology and social psychology to his wonderful teaching. Even more importantly, his calm and steady presence has been invaluable during the hectic and trying time that is completing a doctoral program. I am also thankful for Jill Adelson, who has been an inspiring example of balance in academia. She has generously provided me with opportunity after opportunity, continually reinforcing her belief in my ability to succeed. Even from afar, she has taken the time to help me navigate through difficulties, as well as cheer me on in accomplishments. I would not be able to engage in the qualitative research that fuels my passion for this project without the excellent instruction from Meera Alagaraja. She has changed the way I see myself as a scholar, and has given me a renewed sense of excitement for analyzing data. 
I struggle to find the words to express what Kate Snyder's mentorship means to me. With her guidance and support, I have stepped into my potential as a scholar, and an educator. The opportunity to research, write, and teach alongside her has been an honor. I am forever changed.

I owe a great deal of thanks to my family for encouragement. I am blessed with in-laws, Kevin and Denise, who have been two of my biggest cheerleaders. My sister, Lauren, has kept me company on the phone to and from campus nearly every day for the past four years. Her fortitude and creative spirit inspire me always. And of course, I am deeply thankful for my parents their unconditional love. To make them proud has always been my goal.

I also want to acknowledge the incredible friends that have held my hand through the highest highs and the lowest lows. I am thankful to Brittany Lenihan, whose friendship has been a source of solace for 15 years and to Christa Kaodi, who has always been there when I need her. I am also grateful for the incredible women I have met during my program. To Shelby Burton and Kelsea Visalli, for immediately embraced me into friendship, and for lighting the way ahead of me. And to Abbie Sell, whose caring nature and sense of humor brought joy to every week.

Finally, the process of collecting data for this dissertation was not an easy one. I owe specific thanks to the students of Kate Snyder's Research Methods \& Statistics Course (PSY 220) at Hanover College, as well as Abbie Sell's Human Development and Learning Course (EDTP 107) at the University of Louisville for their assistance with 
pilot testing. I want to thank my many other friends, family, and colleagues who shared my survey in their networks. I could not have done it without you. 


\section{ABSTRACT \\ WE’VE GOT THE 'HOTS' FOR CHANGING TEACHER MISCONCEPTIONS OF \\ LEARNING STYLES: \\ A MIXED-METHODS APPROACH}

Allison Paige Fowler

April 24, 2020

In this dissertation I added to the literature surrounding the myth that teachers should cater to students' learning styles to improve learning outcomes. I operated from the "hot" paradigm for conceptual change, through the use of the Cognitive Reconstruction of Knowledge Model (CRKM) as the theoretical framework to examine teachers' conceptual change about learning styles. More specifically, I considered teachers' existing conceptions as related to their essentialist beliefs, as well as how their motivation and the content of the message contribute to conceptual change. I also responded to the literature on teacher perceptions of researchers by examining the use of teachers themselves as the source of the message prompting conceptual change.

I used a mixed methods approach, conducting both a multiple regression and a qualitative coding analysis. I measured teachers' conceptual change about learning styles after randomly assigning those who endorsed learning styles to receive a conceptual change text (refutation vs, expository) from a source (teacher vs. researcher), and after 
measuring their level of essentialist beliefs. I included level of essentialism, source type and text type in a model, along with a control for grade level. The model did not significantly predict teachers' conceptual change about learning styles $F(5,112)=1.26, p$ $=.28, R_{2}=.01$. I uncovered ten major themes about teachers' experiences with conceptual change about learning styles. Some primary findings were that few participants reported strong conceptual change, with little differences across experimental groups. Participants reported a preference for their own experiences, and were skeptical and critical of research. Teachers who did not endorse learning styles consistently reported that an exposure to and understanding of empirical evidence was instrumental in their conceptual change.

This study adds to the literature on conceptual change and debunking learning styles. The primary limitations include a small sample size and a need for additional scale development, content, and construct validity. I discuss theoretical implications, as well as implications for educational practices. Finally, I discuss potential avenues for future research in conceptual change about learning styles. 


\section{TABLE OF CONTENTS}

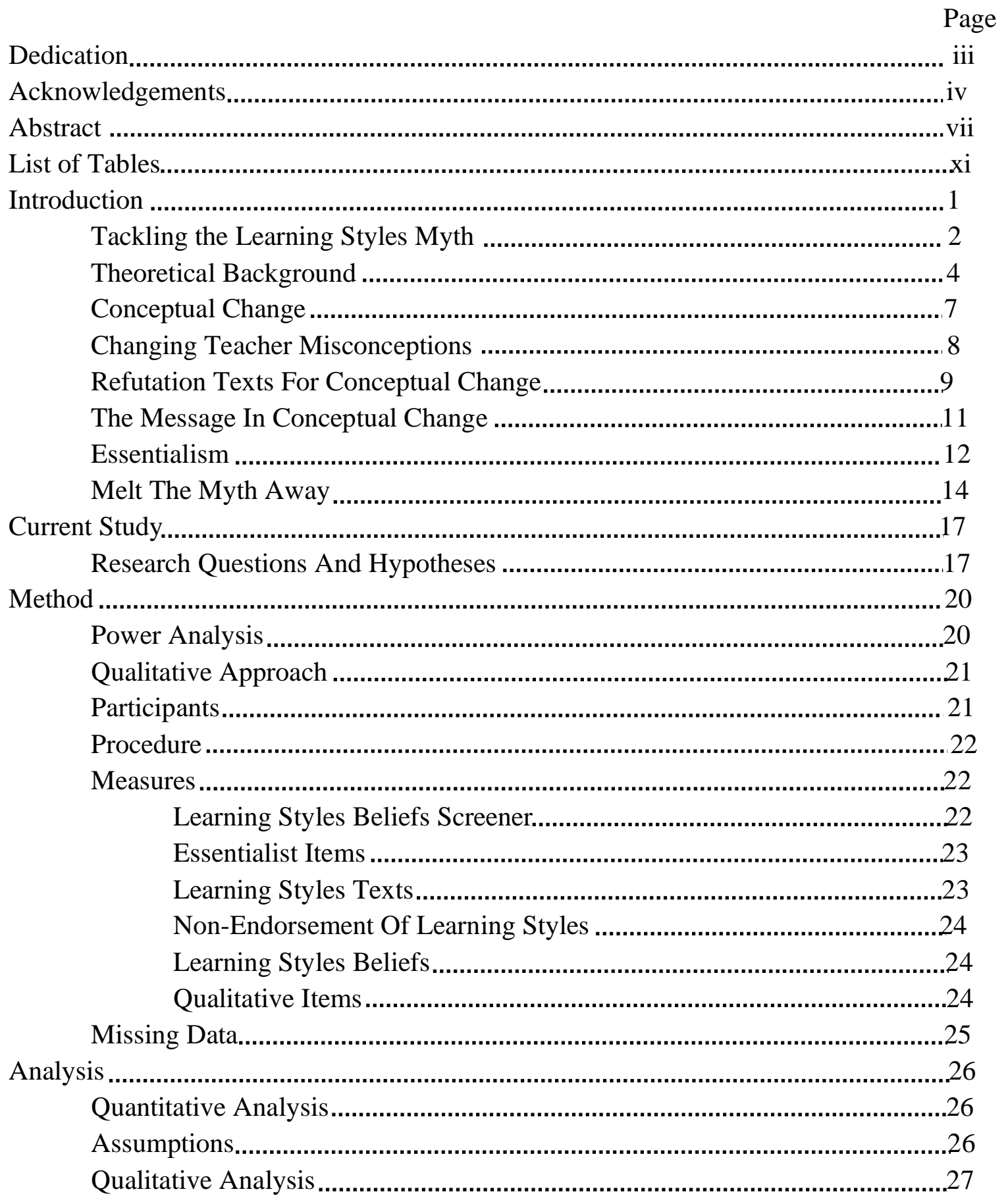




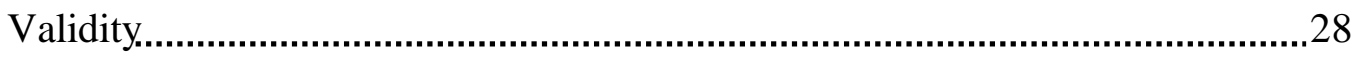

Positionality ............................................................................................ 28

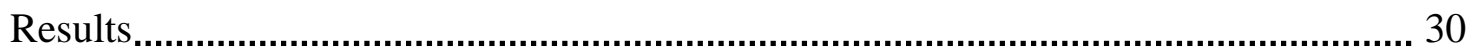

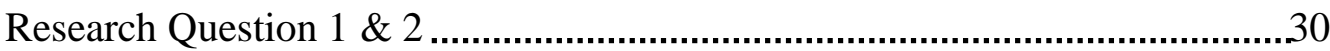

Research Question 3 ......................................................................... 31

Theme 1 ................................................................................................. 31

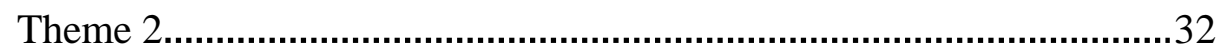

Theme 3 ............................................................................................. 34

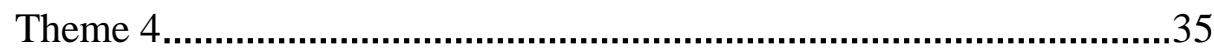

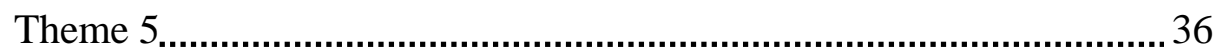

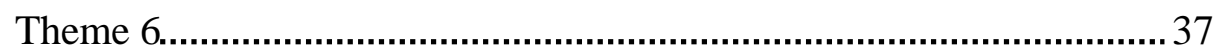

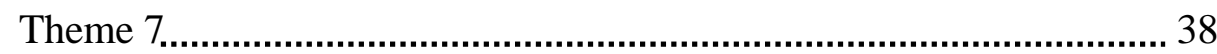

Research Question 4..................................................................................... 39

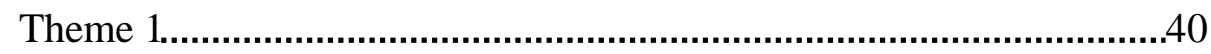

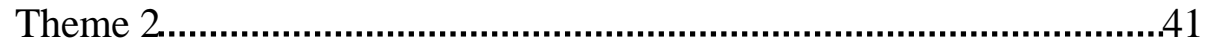

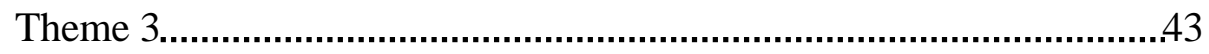

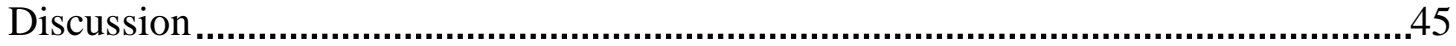

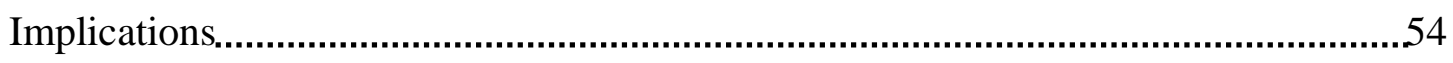

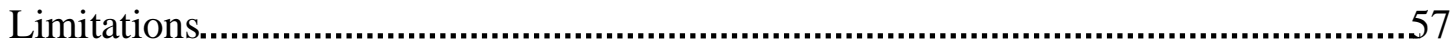

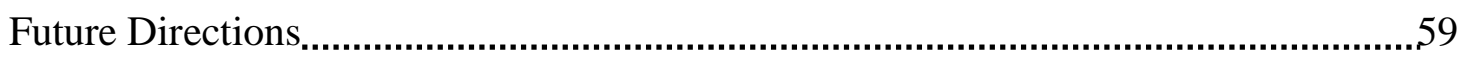

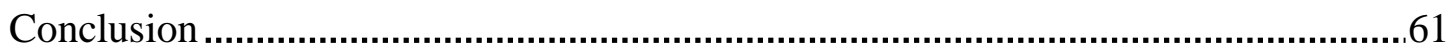

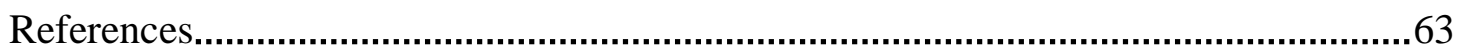

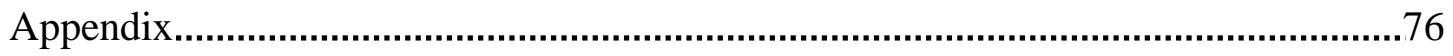

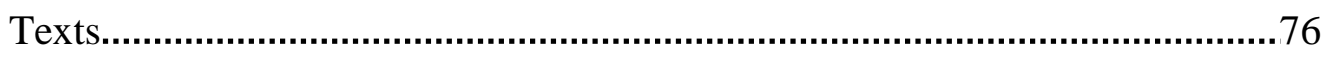

Figures

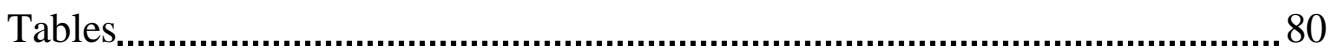

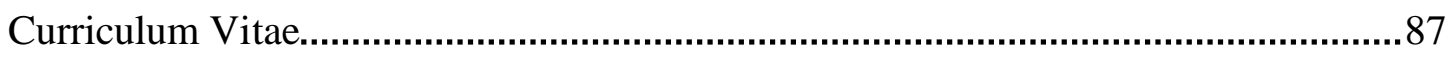




\section{LIST OF TABLES}

TABLE

PAGE

1. Descriptive Statistics for Measures ..................................................... 80

2. Mean and Standard Deviation of Learning Styles

Items Scores by Experimental Group......................................................81

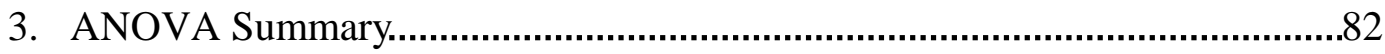

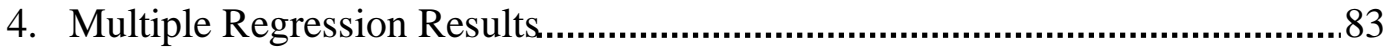

5. Coding Frequency- Learning Styles Endorsers..........................................84

6. Coding Frequency- Learning Styles Non-Endorsers...................................85

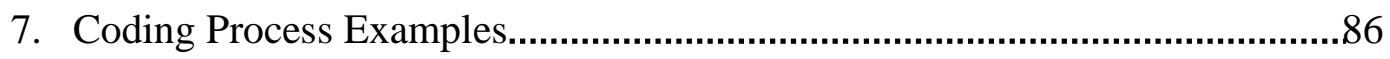




\section{INTRODUCTION}

The learning styles theory refers to the belief that students have individualized modes of learning and that they learn more easily and effectively when they receive material that matches their particular mode (Kolb, 1971; Riener \& Willingham, 2010). This theory has been accepted as truth by the field of education for decades (Newton, 2015), despite the lack of any empirical evidence. In this manuscript, I use the term "learning styles" to refer to students' modes of receiving learning material in an auditory, visual, or kinesthetic manner, as those are the most common. However, educators and researchers have used the term "learning styles" to refer to a host of different categories including broad vs. narrow learners (e.g., Kholodnaya, 1996), analytic vs. global learners (e.g., Davis, 1975), and converging vs. diverging learners (e.g., Kolb et al., 2001). In the past decade, researchers in educational and cognitive psychology have made efforts to 'bust' the myth that teachers should cater to student learning styles (e.g., Pence \& Snyder, 2017; Kirschner, 2017; Rohrer \& Pashler, 2012; Willingham et al., 2015), pointing out the glaring lack of evidence in support of learning styles based instruction. Despite these efforts, the myth continues to thrive in education at all levels (e.g., Chou, 2017; Huertas et al., 2017; Lu, \& Yang, 2018; van Dijk \& Lane, 2018).

Several researchers note the potential harms of implementing learning styles based instruction in the classroom, including pigeon-holing students, wasting teacher 
resources, and spreading misinformation (e.g., Coffield et al., 2004; Kirschner, 2017;

Newton, 2015; Nancekivell et al., 2019). However, simply pointing out the ways in which beliefs about learning styles are innacurate may not fully prevent the continued use in education. For example, after completing a questionnaire that exposed participants to evidence against the effectiveness of learning styles, one-third of educators reported they would continue using learning styles (Newton \& Miah, 2017). It is important to note that these were postsecondary educators, the area where beliefs in learning styles are leastpopular to begin with (Nancekivell et al., 2019); presumably, among teachers of younger children, beliefs about learning styles would be even more impervious to evidence. In order to avoid the potential harms that accompany beliefs in learning styles, it is important that we effectively change teacher misconceptions. We can potentially achieve that goal by moving beyond the presentation of evidence alone, and working towards a more effective method for conceptual change.

\section{Tackling the Learning Styles Myth: What Researchers Have Done So Far}

According to the learning styles theory, when teachers present material in learners' preferred learning modality, learning is more effective (Willingham et al., 2015). Researchers have empirically tested this prediction many times, and the results of those experiments indicate that tailoring instruction to learning preferences does not cause individuals to learn better (Pashler et al., 2008). In their review of the learning styles literature, Pashler and colleagues outline the necessary evidence to support the learning styles theory prediction. Most importantly, the authors noted the need for a style by treatment interaction in the literature, to provide evidence that matching learning material to learning style was effective. Only one such study met the requirements 
(Sternberg et al., 1999), and with them some suspicious methodological decisions, including the unexplained exclusion of participants. Beyond the lack of evidence in favor of learning styles, there is a wealth of evidence suggesting that teachers can implement the most effective learning strategies generally, instead of tailoring to individual students (Brown et al., 2014)

Few researchers take a conceptual change approach by providing educators and parents with evidence-based learning strategies to use instead of learning styles (Pence \& Snyder, 2017). Beyond the work researchers publish in journal articles, many have also taken to social media to spread both an awareness of the myth, as well as express frustration with its continued use in education settings. As an example, Dr. Daniel Willingham published a video on YouTube titled "Learning Styles Don't Exist" that has reached nearly half a million views. Unfortunately, the majority of videos on the topic are in support of the theory and have accumulated millions of combined views, far outnumbering the reach Dr. Willingham's video may have.

Although there is a growing literature base focused on debunking learning styles and urging educators to use other strategies, the public support of learning styles continues to be significantly more widespread. In 2017, the United States Secretary of Education, Betsy Devos, referred to herself as a "visual learner" during her confirmation hearing (Toppo, 2019). Additionally, pre-service and in-service teachers continue to receive pro-learning styles information in their training (Praxis, 2019), making it difficult for evidence to the contrary to have a fighting chance.

If we truly mean to put an end to the myth's propagation in education, it may be necessary to move beyond statements about the fact that learning styles are a myth 
(Newton \& Miah, 2017). Some researchers shifted their focus to who and why so many people believe in learning styles (Newton \& Miah, 2017; Willingham, 2009), but on the whole, we have spent little time investigating how we can effectively change learning styles beliefs.

\section{Theoretical Background: Cognitive Reconstruction Of Knowledge Model (CRKM)}

To address the need to understand how learners construct knowledge, change beliefs, and alter misconceptions, Dole and Sinatra (1998) proposed the Cognitive Reconstruction of Knowledge Model (CRKM; Figure 1), which integrates research about conceptual change in cognitive and social psychology, as well as research on effective science education. This model integrates the relevant factors involved in conceptual change including the prior knowledge of the learner, the learner's motivation for conceptual change, and the message.

The CRKM divides motivation into four categories: dissatisfaction, personal relevance, social context, and need for cognition. These motivational factors interact with the message, or new information, presented to learners. To promote conceptual change, Dole and Sinatra (1998), in line with Strike and Posner (1992), note that learners must be able to understand the message (comprehensible) and be knowledgeable enough about the information to interact with it (plausible). The message must also 'make sense' to the learner in terms of its connection with the phenomena (coherent) and lastly, the message must be persuasive to the learner (rhetorically compelling). The CRKM model shows that the interaction between learner prior knowledge, motivation, and the message impact the strength of the engagement in the message and the strength of conceptual change (Figure $1)$. 
Both usefulness and situational interest (among many motivational factors) fall under the 'Personal Relevance' dimension of the 'Motivation' component of the CRKM. The model posits that in order for conceptual change to occur, learners need to be motivated by one or more of the following factors: dissatisfaction with their existing conceptions, a need for cognition, social contexts, and personal relevance. Within the context of educators' learning styles beliefs, there appears to be little dissatisfaction with their existing conceptions. This is due to the consistent reinforcement of the belief, and its dominance among educators.

'Need for cognition' refers to the motivation to process or learn information. For example, some people may be more inclined to seek out mentally challenging tasks such as crossword puzzles, a behavior that researchers consider high in 'need for cognition'. It is difficult to predict where educators fall in their motivation to process information about learning styles. The need for cognition may be conceptually related to intrinsic motivation, in that it promotes engagement based on a desire to understand (Hoffman \& Nadelson, 2010). The 'social context' dimension of the model is particularly interesting to consider in teacher learning styles beliefs. The endorsement of learning styles based instruction is common (Newton, 2015), and teachers likely experience support from other educators for the implementation of learning styles in the classroom, as the theory has been an integral part of their training with knowledge about learning styles included in teaching licensure exams (e.g., Praxis, 2019). Should endorsement of learning styles be less socially reinforced among educators, it may be easier for individual teachers to engage in conceptual change. 
Researchers use the CRKM to better understand conceptual change in learners. In a study examining student learning about new concepts in physics, the motivation component of the CRKM was linked to student conceptual change. However, 'need for cognition'- a factor within the motivation component- was not related to conceptual change (Taasoobshirazi et al., 2016). As previously mentioned, it is difficult to predict where teachers will fall in their 'need for cognition' about their learning styles beliefs, in part because many teachers have not been exposed to evidence against learning styles, and therefore may not feel a need to think more critically about the theory. Moreover, it may be the case that 'need for cognition' is less important for conceptual change than other components of the CRKM.

Jones and colleagues (2015) examined the CRKM by modeling the relationship between attention allocation, cognitive engagement, and conceptual change about the common cold. The findings suggest that greater attention to the material was related to more cognitive engagement and therefore, more conceptual change. Another group of researchers used the CRKM as a framework to examine conceptual change in learners' beliefs about the human papillomavirus (HPV; Hilpert \& Brem, 2013). The findings provide evidence in support of the CRKM, particularly 'dissatisfaction' with the belief along with 'engagement'. More specifically, an increase in dissatisfaction led to an increase in knowledge about HPV. This relationship was mediated by engagement. In a study examining achievement goal orientations as they pertain to the CRKM, researchers again found support for the model (Ranellucci et al., 2013). They also note that some components of the CRKM that appear to be more predictive of conceptual change than 
others (i.e., the link between motivation and conceptual change may be stronger than the link between depth of processing and conceptual change).

\section{Conceptual Change}

Conceptual change refers to the alteration of prior knowledge in light of new information (Vosniadou, 1999). Researchers studying conceptual change attempt to understand the mechanisms of the construct, including which factors play a role in both improving and diminishing conceptual change. Prior to Pintrich and colleagues' seminal paper (1993), conceptual change was theorized as a "cold" process, focusing primarily on the role of cognitive factors. The "cold" model relies on the assumption that all individuals experience a change in their beliefs in a scientific and logical manner (Pintrich et al., 1993). In other words, the "cold" model predicts that individuals engage in a rational process of discarding an old conception in exchange for one that better accounts for their new knowledge. Although Posner et al.'s model includes important and relevant factors in conceptual change, the counter theory introduced by Pintrich and colleagues (1993) and many others since (e.g., Heddy et al., 2017; Sinatra et al., 2014) is that conceptual change is far less rational and far more subjective to "hot" motivational factors.

Researchers posit that the recognition and inclusion of "hot" factors leads to a better understanding of conceptual change. Researchers have widely studied the role of motivation in conceptual change and in doing so, have uncovered the complexity of the interaction between information and the self. Aligned with the social cognitive theory, the recent research surrounding conceptual change and the CRKM examines the relationship between cognitive factors such as self-efficacy, situational interest, affect, and 
engagement and behavioral changes. Often researchers aim to observe and model the interactions between multiple motivational factors (Cordova et al., 2014; LinnenbrinkGarcia et al., 2012).

\section{Changing Teacher Misconceptions}

The 'Social Context' factor in the 'Motivation' component of the CRKM is highly related to the conceptual change tools necessary to alter teacher beliefs about learning styles. Some researchers found that current practices in college child development courses such as tenacity of prior knowledge, cognitive biases, and personal epistemologies may actually be impeding conceptual change (McDevitt \& Ormrod, 2008). When the social context element of teaching is considered in conceptual change efforts, results indicate more effective change. In a study examining beliefs held by preservice teachers, the researchers found that by combining teacher inquiry and field experience, they were better able to engage the pre-service teachers in effective conceptual change (Dawson \& Dana, 2007). In a qualitative inquiry, another group of researchers found that their teacher participants reported social-motivational factors (i.e., having processes and responsibilities formed as a group, and learning from interactions with others) as contributing to their conceptual change of professional practice (Reeves et al., 2005). Similarly, researchers showed that community involvement and group discussion were associated with increases in learning and conceptual change (Yough et al., 2015).

As outlined in the CRKM, social contexts play a role in how learners view the message, as well as how deeply they engage with new information. Currently, in-service and pre-service teachers are bombarded with pro-learning styles information, rendering 
their social networks as echo-chambers for learning styles pseudo-science. The learning styles information provided to teachers not only asserts that the different styles exist among their students but also encourages teachers to accommodate students based upon their individual style (e.g., Braio et al., 1997; Cicco, 2009). When creating lesson plans, some teachers are required to include specific differentiation plans for the different styles of learners (e.g., Drexel University School of Education, 2019). The teacher licensing exam, "Praxis Principles of Learning and Teaching", includes student learning styles as an important variable in how students perform (Praxis, 2019). The expectation that teachers should consider students' learning styles in their classroom decisions is not limited to any age group, as state departments of education list learning styles resources in their recommendations for differentiation practices (e.g., Kentucky Department of Education, 2019). Even university websites include information for faculty and staff to use to accommodate for learning styles (e.g., University of Massachusetts Dartmouth, 2019). In many ways the learning styles theory is used less as a piece of information and more as a call to action for teachers. The unified front held by educators on learning styles is powerful. Ideally, researchers would use that unity to promote evidence-based strategies instead.

\section{Refutation Texts for Conceptual Change}

In addition to in-person conceptual change strategies, researchers have also demonstrated promoting effective conceptual change through texts that are deliberately constructed to align with the CRKM and other models of "hot" conceptual change. Refutation texts are tools used to promote conceptual change by going beyond claims that a given belief is incorrect, by both refuting the incorrect belief and providing an 
explanation of the correct belief (Beker et al., 2019). Refutation texts are often more effective in facilitating learning and comprehension of a topic than typical texts that only expose readers to factual information (e.g., Broughton et al., 2010; Diakidoy, et al., 2003; Diakidoy et al., 2011).

Researchers do not fully understand the exact mechanisms by which refutation texts lead to conceptual change. However, researchers have suggested a few possibilities that may help explain why refutation texts appear to improve learning and conceptual change. In line with the CRKM, refutation texts address key factors of both the 'Motivation' and the 'Message' components, such that learners may experience deeper engagement with the new information. Some researchers postulate that refutation texts illicit learner's engagement in meta-comprehension strategies, which in turn allows the learner to be more accurate in their assessments of their own comprehension (Prinz et al., 2019). Additionally, other researchers suggest that refutation texts require deeper processing which in turn leads to better comprehension of information (Ariasi et al., 2017). Tippett (2010) points to the refutation text's activation of learners' prior knowledge as critical in its effectiveness. Other possibilities include the coactivation of misconceptions and new information, as well as the additional attention readers give to the interesting and shocking information found in refutation texts (Sinatra \& Broughton, 2011).

Enjoyment of an activity has long been linked to an increase in motivation via an increase in situational interest and intrinsic motivation. In line with this, an important quality of refutation texts is that they are well-liked among learners (Guzzetti et al., 1992). In a qualitative study, student participants reported that they liked refutation texts 
for several reasons including being moderately discrepant with belief, understandable, credible, useful, repeated, and related (Hynd, 2001). This quality of refutation texts may play a role in increasing learner situational interest, thereby increasing motivation during the conceptual change process. In a study that examined the role of topic interest in the conceptual change of students reading a text about the science of light, researchers found a statistically significant interaction between topic interest and conceptual change. Those with higher topic interest outperformed those with lower topic interest at post-test (Mason et al., 2008).

\section{The Message in Conceptual Change}

Related to the motivational aspects of conceptual change is the message itself. The CRKM model outlines the needs of the message to be comprehensible, coherent, plausible, and rhetorically compelling. Most important for this study is the need for the message to be rhetorically compelling. This aspect of the message involves primarily the source of the information. There has been little exploration of the relationship between source credibility in the conceptual change of teachers. However, there is reason to believe that teachers are hesitant to trust non-teacher voices, particularly as it pertains to classroom practices.

In a qualitative inquiry into teachers' experiences working collaboratively with researchers on professional developments, teachers reported feeling negatively about working with researchers. That was in part because they viewed the research as not actually relevant to their immediate classroom needs (Gutierez \& Kim, 2017). In another study that examined pre-service teacher beliefs about the usefulness of research in their profession, the researcher found that some pre-service teachers viewed research as 
disconnected from their practice (Yancovic-Allen, 2018). Similarly, when asked about their own use of studies, only $33 \%$ of teachers report that they benefit from the findings of educational research (Sari, 2006). Some of the reasons teachers cite include a disbelief in the credibility of the results of research, and the belief that the research is not well linked to teachers' "real" problems . Teachers may respond better to research when it comes from other teachers, because of a perception that this research is more strongly related to their classroom experiences and needs (Reis-Jorge, 2007).

\section{Essentialism}

An essentialist belief refers to the assumption that certain qualities or phenomena are innate, or biologically predetermined (Gelman, 2003). For example, an essentialist belief in philosophy may be that human nature is a constant and unchangeable quality shared by all of humanity. Such beliefs are not without criticism, particularly for their use to inform and validate prejudice (e.g, Rhodes \& Mandalaywala, 2017). People hold essentialists beliefs about a wide variety of topics such as gender (e.g., Gowaty, 2018), morality (e.g., Heiphetz, 2019), and animals (e.g., Emmons \& Kelemen, 2015). Within the realm of education, people hold essentialist beliefs about intelligence and giftedness (e.g., Räty et al., 2017), single sex education (Fine \& Duke, 2015), and more recently, researchers have begun to explore the essentialist belief in learning styles (Nancekivell et al., 2019).

Essentialist beliefs are situated within the CRKM as the learners' existing conceptions. Also referred to as 'prior knowledge', a learner's existing conceptions can impact their interpretation of the new information (Cordova et al., 2014). The CRKM outlines three qualities of existing conceptions, each of which uniquely effect conceptual 
change. An existing conception is stronger if it is well-formed. These stronger conceptions may be more difficult to change. Next, the CRKM includes the coherence of a conception. A conception is more coherent if it can provide good evidence for an idea, and less coherent if it can only partially explain an idea. Similar to strength, conceptions with greater coherence are also more difficult to change. The last quality of an existing conception is the learner's commitment to that conception. When learners are highly committed to an idea or belief, it can again be more difficult to induce conceptual change. The commitment quality may be less rational and not contingent upon strength or coherence.

Nancekivell and colleagues (2019) published an exploration of the learning styles myth in which they examined nuances and important distinctions among the types of beliefs in learning styles. They categorized the learning styles belief into two categories: the essentialist view and the non-essentialist view. The found important differences between essentializers and non-essentializers in their learning styles beliefs, "The essentializers were more likely to view learning styles as determined at birth, unchanging, detectable in the genes, heritable, mutually exclusive, marking distinct kinds of people, instantiated in the brain, and predictive of career and school outcomes" (Nancekivell et al., 2019, p. 12).

Among teachers, they found that those who worked with younger students were more likely to hold essentialist beliefs about learning styles, with pre-school teachers being most likely (88\%), and high school teachers being least likely (32\%). In their discussion of their findings, the authors urge researchers to move beyond examining the rate at which learning styles beliefs are endorsed, and instead begin to explore the 
nuances of the belief, particularly the role of essentialism, as it may be more problematic and more resistant to change.

When it comes to constructing an accurate understanding of the world, essentialist beliefs can at times become a barrier. This hindrance is known as the 'essentialist constraint' (Gelman, 2003), and is a form of cognitive bias that may prevent learners from changing misconceptions (Sinatra et al., 2008). In constructivist terms, essentialism is related to the construction of information in our schemas. When we encounter new information that challenges our current understanding, we experience disequilibrium and are often prompted to accommodate our schemas by changing them or creating a new schema to fit the information. Holding an essentialist belief may cause us to view certain new information as unconvincing, or even to outright reject it, instead of prompting us to accommodate. In the case of learning styles beliefs, essentializers might have difficulty conceding that a person whom they identify as a visual learner would ever learn in another style. In the CRKM, this resistance to conceptual change could be a result of the learners' existing conception strength, coherence, or commitment. Essentialist beliefs in learning styles are a very new area of research, and there are currently no studies exploring how or why learners' existing conceptions about learning styles are resistant to change.

\section{Melt the Myth Away}

The learning styles myth remains popular in education and teacher training from elementary to college levels (e.g., Drexel University School of Education, 2019; Praxis, 2019;). Researchers have made many efforts over the past few decades to spread awareness that the learning styles theory is unfounded. They implore teachers to stop 
using learning styles in the classroom as a means of promoting learning and achievement outcomes (Pashler et al., 2008). Furthermore, the claims that some pro-learning styles advocates make about the effects of learning styles-based instruction are outright deceptive and shocking. For example, the following claims made by Rita Dunn, a prominent pro-learning styles researcher, "Within six weeks, I promise you, kids who you think can't learn will be learning well and easily ... The research shows that every single time you use learning styles, children learn better, they achieve better, they like school better" (Coffield et al., 2004; O’Neil, 1990, p. 7). In order to continue to fight for a better education for our students, it is important that researchers begin exploring other methods for conceptual change about learning styles.

The two most popular articles addressing learning styles myths are the literature review conducted by Pashler and colleagues (2008) and the systematic review conducted by Coffield and colleagues (2004). Although both reviews are thorough sources of information about the learning styles literature, neither paper draws on motivational factors to change reader conceptions. Instead, the aim of both reviews is to examine the literature, rather than to actively debunk. Since those reviews, other researchers have published papers that do go beyond a review of the evidence against learning styles, and instead focus on the wealth of evidence-based strategies that educators should use instead (e.g., Kirschner, 2017; Newton, 2015; Willingham et al., 2015). One could reasonably argue that the presentation of evidence-based strategies is "warmer" in terms of conceptual change when compared to the review, and I would agree. That being said, there remains the issue of the teacher-researcher relationship. To begin, little of the research debunking learning styles is directed at teachers, but instead remains in the 
academic circle. There are some notable exceptions, including a paper published in Teaching for High Potential (Pence \& Snyder, 2017), a journal consumed predominantly by teachers, along with Kirschner's (2017) article directed at gatekeepers. The issue of academics predominantly communicating with one another is compounded by the hesitancy teachers have to trust or use advice coming from researchers (Gutierez \& Kim, 2017; Sari, 2006; Yancovic-Allen, 2018). When it comes to strong conceptual change, it appears that a teacher's voice may be most motivating and compelling to alter the beliefs of another teacher. By acknowledging this, we can better incorporate motivational factors, and in doing so, move towards a truly "hot" model of conceptual change for learning styles beliefs. 


\section{CURRENT STUDY}

In this study, I aim to better understand how to effectively change teacher misconceptions about learning styles. In response to the most recent literature regarding effective conceptual change, I operate from the "hot" paradigm in that I acknowledge and utilize the role of motivational factors in the conceptual change process. More specifically, I use the CRKM as the guiding model to induce conceptual change. Based upon the model, I consider multiple motivational factors, as well as important information about both the learner and the message involved in this conceptual change process. Along with recommendations of the CRKM, I respond to the literature on teacher perceptions of researchers by examining the use of teachers themselves as the source of the message prompting conceptual change. This strategy is also in line with recommendations from Hynd (2001) to increase the credibility and make the message more rhetorically compelling for learners.

\section{Research Questions \& Hypotheses}

1) Do teachers who endorse learning styles experience greater conceptual change after reading an expository text or a refutation text?

1a) Does the source of the text affect the degree of conceptual change?

Based on the theoretical and empirical considerations discussed above, I predict a main effect for text type (participants reading refutation texts will report greater 
conceptual change) and a main effect for source type (participants reading text from a teacher source will report greater conceptual change).

2) Do the teachers' identities as more or less essentialist affect the degree of conceptual change?

In line with the research suggesting that essentialist beliefs may be more resistant to change, I predict a main effect of essentialist belief (those with greater reported essentialist beliefs in learning styles will report less conceptual change). Furthermore, I predict an interaction effect of essentialist belief, source, and text type (those with greater essentialist beliefs will report the least conceptual change when randomly assigned to the expository text condition with the researcher source and will report the most conceptual change when randomly assigned to the refutation text with the teacher source.)

3) How do teachers describe their experience with conceptual change (or lack thereof) following reading the information in the texts?

I predict that the qualitative data will corroborate the quantitative data and that participants will describe their experience reading refutation texts from a teacher source as more convincing and compelling than expository texts or texts from a researcher source.

4) How did teachers, who currently do not endorse a belief in learning styles, form their conceptions about the phenomenon?

In order to better shape how we continue to change misconceptions, it will be beneficial to understand how misconceptions have been successfully changed in the past and how correct conceptions have been formed. Because an endorsement of learning styles is the dominant belief among educators, I predict that few participants will self- 
identify as not endorsing a belief in learning styles. For this reason, I believe it is especially important to capture the formation for those who hold the accurate belief. I predict that those who do not endorse learning styles will have taken a course in their teacher training that explicitly debunked the belief. 


\section{METHOD}

I used both quantitative and qualitative methodology in order to attain a robust picture of the process of conceptual change about learning styles beliefs for teachers. The analysis included three predictors, one continuous and two with two levels. Additionally, I included the grade level taught by the teachers as a control in the model. The continuous predictor was the participants' level of essentialism. The other predictors were text type (refutation vs. expository) and source type (teacher vs. researcher). Participants' conceptual change as measured by their learning styles endorsement score following exposure to the different experimental text conditions served as the outcome of interest.

\section{Power Analysis}

I conducted a power analysis using $\mathrm{G}^{*}$ Power to determine appropriate sample size to have adequate power to detect an effect. I set the power at .80 and the alpha level at .05 , in line with recommendations for social sciences research. The predicted effect size for the main effects of this intervention is $d=0.22$, based on a meta-analysis of conceptual change texts (Guzzetti et al., 1992). The results from G*Power recommend a sample size of 1,369 in order to detect an effect of $d=0.22$ with power of .80 .

\section{Qualitative Approach}

I rely on the phenomenological approach in the qualitative portion of this study. The phenomenon of interest is the acquisition of the common belief in learning styles held by many teachers. The purpose of a phenomenology is to discover and then describe 
the experiences of the participants (van Manen, 1990); thus, in this study, I am to gain insight into how teachers themselves describe their experiences holding or rejecting the belief in learning styles. As the researcher, I position myself in a way that I am able to acknowledge the role that my own experiences and biases play in my interpretation of the phenomenon. However, the words and experiences of my participants are the primary knowledge I use to access the essence of the experience (van Manen, 1990, Creswell, 2017). In line with the qualitative interpretive framework of social constructivism, this study underscores the importance of constructing meaning through experiences (Creswell, 2017, p. 24).

\section{Participants}

I recruited participants online and through snowball sampling. The inclusion criteria for participants included being $18+$ years in age, currently employed as an inservice teacher, a U.S citizen, and proficient in the English language. 141 participants agreed to participate in the intervention and met the inclusion criteria, however the quantitative analysis is based upon the 118 participants who endorse learning styles. $82 \%$ $(n=115)$ of participants identified as female, $16 \%(n=22)$ identified as male, and $3 \%(n$ $=4)$ preferred not to answer. The racial breakdown of participants was $90 \%(n=127)$ White/Caucasian, 4\% $(n=6)$ preferred not to answer, 2\% $(n=3)$ Hispanic/Latinx, $1 \%(n$ =2) Black/African, 1\% $(n=1)$ Asian, 1\% $(n=1)$ Other, and 1\% $(n=1)$ two or more races. The mean number of years in the classroom for participants was $13.25(S D=9.7)$. Participants selected the grade level(s) of the students they currently worked with from the options preschool-kindergarten, 1st-3rd, 4th-5th, 6th-8th, and 9th-12th. The primary category included $47 \%(n=66)$ of participants, and the secondary category included 53\% 
$(n=75)$ of participants. The majority of participants $84 \%(n=118)$ endorsed a learning styles belief, with only $16 \%(n=23)$ reporting not believing in learning styles or being unsure.

\section{Procedure}

After signing in, participants answered the learning styles screening question, along with the distractor questions. Those who reported not endorsing learning styles received open-ended questions about their learning styles stance. The participants who did report endorsing learning styles then completed the essentialist survey, and were randomly assigned to text conditions. After exposure to the texts, participants responded to the learning styles belief items and qualitative open-ended questions about their conceptual change experience. At the end of the survey, participants provided demographic information.

\section{Measures}

\section{Learning Styles Belief Screener}

At the start of the survey participants received a series of seven questions regarding their beliefs about student learning. Of those questions, six were distractors and one directly addressed their beliefs about learning styles reading, "Rate your agreement with the following statement: Individuals learn better when they receive information in their preferred Learning Style (e.g., auditory, visual, kinesthetic)". This wording is consistent with previous literature (Newton \& Miah, 2017). Participants responded to the questions on a 5-point Likert scale. Those who indicated support for the claims of learning styles by choosing 'Agree' or 'Strongly Agree' moved on to the survey, which assesses their essentialist beliefs and then randomly assigned them to one of four 
experimental conditions. Participants who indicated doubts about the claims of learning styles by choosing 'Neither Agree Nor Disagree', 'Disagree' or 'Strongly Disagree' instead received a series of open-ended questions about their beliefs.

\section{Essentialist Items}

Participants responded to 15 items categorizing them as either essentialist or nonessentialist (Nancekivell et al., 2019). In this study, the participants' level of essentialism is a continuous variable. Participants rated their agreement with each item on a 6-point Likert scale ranging from 'Strongly Disagree' to 'Strongly Agree'. A sample item is, "A person's learning style is determined at birth." Higher agreement indicates stronger essentialist beliefs. However, some items (e.g., "A person can have multiple learning styles") were reverse coded. Nancekivell and colleagues (2019) report a Cronbach's alpha of .71 for internal consistency reliability. The internal consistency reliability for the participants in the current study is $a=.77,95 \% \mathrm{CI}[.7, .82]$. I calculated participants' scale score by averaging the scores for the 15 items.

\section{Learning Styles Texts}

The expository text provided factual information about the learning styles myth but did not address any correct information to counter the learning styles theory. This text was 154 words (12 sentences) and earned a Flesch Reading Ease score of 64.2 (standard/average). The refutation text included information about the incorrect misconceptions and provided correct information to counter the learning styles theory. The refutation text was 226 words (17 sentences) and earned a Flesch Reading Ease score of 60.5 (standard/average). The full texts were written by me and are located in the Appendix. 


\section{Non-endorsement of Learning Styles}

Participants who reported not endorsing a belief in learning styles received a set of open-ended questions about their beliefs. The questions included 1) Describe your current beliefs about learning styles 2) If applicable, describe how your beliefs about learning styles ever been different than they are currently? 3) Describe the evidence against learning styles that you find most convincing and why. and, 4) The belief that learning is more effective when student materials match with their preferred learning styles is popular. Why do you believe educators so often hold this belief?

\section{Learning Styles Beliefs}

To measure conceptual change, participants responded to three items measuring their beliefs about learning styles on a 5-point Likert scale ranging from 'Strongly Agree' to 'Strongly Disagree'. Higher values indicate greater conceptual change. This method of measuring conceptual change was adapted from previous research that uses comparisons between pre- and post-text knowledge (e.g., Heddy et al., 2017). The three items are as follows: "Providing my students with material that matches their learning style will help them learn more.", "There is evidence to support the use of learning styles-based instruction.", and "Teachers should use learning styles-based instruction." I conducted a pilot test of these items with 45 undergraduate students. During this pilot, I also received feedback from the participants about the content and wording of the items to ensure clarity and establish some evidence for content validity. The internal consistency reliability for the scale is $\mathrm{a}=.83,95 \% \mathrm{CI}[.76, .88]$. I calculated participants' scale score by averaging the scores for the 3 items.

\section{Qualitative Items}


In addition to these items, participants responded to open-ended questions about their experience reading texts that provide evidence against learning styles. The openended questions included: 1) To what extent did reading the text affect your beliefs about learning styles? 2) Describe your reactions to the claims about learning styles made in the text and, 3) In what ways did the author's expertise affect your perceptions about the information (if at all)?

\section{Missing Data}

Prior to analysis I established the rule that if participants responded to at least two-thirds of items on each scale (10 out of the 15 essentialism items and two out of the three learning styles items), I kept the participant for analysis and used the mean of their responses. This was the case for just three participants. If participants did not respond to at least two-thirds of items on each scale, I removed them from the data. I removed a total of 43 participants due to missing data. Of those 43 participants missing scales, 22 were missing both the Essentialism scale and the three learning styles beliefs items. The remaining 21 participants completed the Essentialism scale, but did not complete the learning styles beliefs items. 


\begin{abstract}
ANALYSIS
Quantitative Analysis

I used a multiple regression to conduct the analyses in this study. This analysis included the 118 participants who endorsed learning styles and were not missing more than two-thirds of the scale data. I centered the essentialism scores for participants. Degree of essentialist beliefs, type of conceptual change text intervention (expository vs. refutation text), and text source (researcher vs. teacher) served as the independent variables. The model also includes the essentialism by text type by source type interaction term. Additionally, I included the grade level taught by the participants as a control in the model. I recoded this variable as binary, categorizing teachers as either primary (preschool through 5th grade) or secondary (6th grade through 12 th grade). My rationale for coding grade level as binary was that $15 \%(n=18)$ participants chose more than one category to represent the grade levels they currently teach. In order to examine potential differences between teaching younger and older students (Nancekivell, 2019), I needed to broaden the categories to account for the larger grade level spans selected by the participants. The dependent variable in the model was the conceptual change as measured by learning styles beliefs following the text.
\end{abstract}

\title{
Assumptions
}

The assumptions of a linear multiple regression are that the relationship between the dependent variable and the independent variables is linear, that there is no 
multicollinearity, that the residuals are independent, that the data are homoscedastic, that the residuals are normally distributed, and that there are no outliers biasing the model. To examine linearity, I plotted the relationship of each independent variable with the dependent variable. The resulting scatterplots confirmed the linear relationships. Multicollinearity exists when the independent variables in the model are highly correlated with one another. In this model, the independent variables are the essentialist beliefs, the text type, and the source type. The latter two are randomly assigned and should be uncorrelated with both one another and the essentialist beliefs. Additionally, the independent variables in this model are not conceptually related. To confirm the absence of multicollinearity, I examined the variance inflation factor (VIF) of the predictors. The VIF values for the predictors in the model were unconcerning, ranging between $1.0-1.3$. The results of the model are least robust to violations of the assumption of independence, and as such, I took precautions to ensure this assumption was not violated. The precautions are primarily implemented in the design, as the participants are drawn from a wide pool and are not nested in any non-trivial manner. To ensure the data were homoscedastic, I viewed scatterplots of the residuals, which indicated equal variances from the regression line regardless of differences in the value of the independent variable. To determine that the data were normally distributed, I examined P-P plots to view the distribution of the residuals. Finally, to ensure there were no outliers biasing the model, I examined the Cook's Distance statistic for each participant, which were all less than 1 indicating no presence of outliers.

\section{Qualitative Analysis}


The coding process for the open ended questions included multiple phases. In the first phase, I initially read the open ended responses to gain an initial understanding of the words of my participants. Next I used open coding and eclectic coding, during which I read through the responses a second time, highlighting the significant words and phrases from my participants. I also used the NVivo software and Excel to assist in the coding process. I coded each open ended question separately, and I organized the responses by participants' level of essentialism, as well as by participant condition. In addition to eclectic and open coding, the second cycle coding included concept coding to capture the broader ideas that participants discussed, as well as some causation coding to note patterns of participants' conceptual change timeline. Additionally, throughout the entirety of the coding process I used analytic memoing. This is a crucial aspect of coding, in that it allows me to iteratively shift from coding to conceptualizing the words of my participants in order to construct the most accurate depiction of the phenomenon from their experience. I used the codes created during this process to identify key themes, which I outlined and described in the results section of this study. Coding frequency tables and a coding process table are located in the Appendix.

\section{Validity}

I relied primarily on peer debriefing as the validation strategy (Creswell \& Miller, 2000) during the analysis process. I discussed the participant responses, the codes, and the creation of the major themes with fellow researchers who are familiar with the phenomenon of interest. I received multiple rounds of feedback on my coding, analyses, and findings.

\section{Positionality}


In order to provide as much transparency as possible, as well as to share my own experience and bias with the phenomenon, I share my researcher positionality. My experience with learning styles began like many others in school as a child when I took an inventory that identified me as a visual learner. The importance of catering to student learning styles was further impressed on me during my undergraduate degree studying education. We were required to include specific accommodations in each of our lesson plans for the different types of learning styles popular at that time: visual, auditory, and kinesthetic.

I was exposed to evidence against the efficacy of learning styles very early in my doctoral program, and can understand first-hand the surprise and frustration felt by teachers when they are presented with such conflicting information. However, unlike many teachers, I shifted my career path away from classroom teaching and into academia. Immersed in a research environment, instead of receiving constant reinforcement that learning styles mattered, I was receiving the opposite.

However, my role as an instructor for pre-service teachers kept me well-informed about the continued pervasiveness of the learning styles myth. I integrate explicit debunking in my course, and have broken the news about learning styles to well over 100 pre-service and in-service teachers. I understand the difficulty of engaging my students in conceptual change about learning styles, but more importantly, I understand the need for the fields of education and psychology to put an end to the promotion of learning styles based instruction. 


\section{RESULTS}

\section{Research Questions 1 \& 2}

I conducted a multiple regression analysis to answer the first two research questions. I sought to determine if teachers who endorsed learning styles experienced greater conceptual change after reading an expository or refutation text, and if the source of the text affected the degree of conceptual change. I also sought to determine if conceptual change was affected by teachers' identities as more or less essentialist. Descriptive statistics for these analyses are presented in Table 1 (overall) and Table 2 (by group). The results of the linear multiple regression indicate that the model was not a significant predictor of participants' conceptual change about learning styles $F(5,112)=$ $1.26, p=.28$ (see Table 3 ). The model explained approximately $1 \%$ of the variance in participants' conceptual change about learning styles. None of the individual predictors were statistically significant controlling for the other predictors in the model. Teachers receiving a refutation text scored .21 points higher ( \pm .29 points, $p=.17$ ) on the measure of conceptual change than teachers receiving an expository text. This non-statistically significant effect was in the predicted direction. Teachers receiving a text purportedly written by a teacher scored .20 points lower ( \pm .30 points, $p=.21)$ on the measure of conceptual change than teachers receiving a text purportedly written by a researcher. This non-statistically significant effect was not in the predicted direction. The effect of essentialism was in the predicted direction: for every one point increase in essentialism, 
teachers' scores on the measure of conceptual change decreased by an average of .26 points ( \pm .19 points, $p=.12$ ). The non-significant effect of grade level was also in the predicted direction: Teachers who indicated that they taught older students showed more conceptual change ( .08 points on average, \pm .32 points, $p=.55$ ). The essentialism by source type by text type interaction was not statistically significant $(b=-.002, p=.99)$. Descriptive statistics and results are in Tables 1 and 2, and Table 4 presents the multiple regression results (Appendix).

\section{Research Question 3}

I conducted a qualitative analysis of the open-ended questions answered by participants who reported endorsing learning styles. This analysis provided answers to the research question, "How do teachers describe their experience with conceptual change (or lack thereof) following reading the information in the texts?" I uncovered seven major themes, which I describe in detail below. Fewer participants responded to the qualitative open-ended questions than the quantitative multiple choice questions. Question 1, "To what extent did reading the text affect your beliefs about learning styles?" had a $71.2 \%$ response rate $(n=84)$. Question 2, "Describe your reactions to the claims about learning styles made in the texts." had a $66 \%$ response rate $(n=78)$. Finally, Question 3, "In what ways did the author's expertise affect your perceptions about the information (if at all)?" had a $62 \%$ response rate $(n=73)$.

\section{Theme 1: More Than None but Less Than All}

I asked participants to identify the extent to which reading the text affected their beliefs about learning styles. The largest category of participant responses $(n=43)$ expressed experiencing something in between no conceptual change and a total shift in 
beliefs. Although these participants did not concede that they changed their minds about learning styles, they did express a more critical reflection of their beliefs (e.g., "It made me second guess what I thought I knew and was previously taught about learning styles instruction.", "It made me consider that perhaps [learning styles] didn't play as big of a role as I anticipated.”). On one far end of the spectrum were the participants who reported no change in their beliefs $(n=22)$. One participant shared that after reading the text they “...still believe[d] students learn a certain way." Another responded similarly stating, "No change in my opinions." On the other end of the spectrum were those who reported that the text had caused them to change their minds about learning styles $(n=15)$. One participant wrote,

Before reading the text, I had assumed that there was research to back the claim that teaching to specific learning styles helps improve student learning. This was something I had been told during my graduate program and my years in the classroom. However, I believe in evidence-based approaches, so upon learning that no studies have actually proved the effects of the learning styles theory, I changed my opinion on it.

\section{Theme 2: Group and Individual Differences Didn't (Usually) Matter}

Although I focused the qualitative portions of the analyses on understanding the description and experience of conceptual change for participants, I also investigated if participants differed in their responses based upon their random assignment and their level of essentialism. I found that on the whole, those group and individual differences did not appear to play a role in the conceptual change of participants. For almost every code, I found that responses were evenly distributed across the four different randomly 
assigned groups. I also sorted participant responses by their level of essentialism, and again, I found no consistent response pattern.

Few participants reported feeling completely convinced by the information in the texts. I coded eight participants as having a "changed mind", based on their responses to the question, "To what extent did reading the text affect your belief about learning styles?". Additionally, I coded five participants as "agreeing" based on their responses to, "Describe your reactions to the claims about learning styles made in the texts." The one area for which I found a pattern in types of responses, was for those who described experiencing the most conceptual change. Of the eight participants coded as having a "changed mind", five received a refutation text. A stronger pattern emerged in the codes for "agreeing", as all five participants received a refutation text.

I hypothesized that the majority of participants would report endorsing learning styles. As I outlined earlier in this manuscript, participants who chose the options 'Agree' or 'Strongly Agree' to the learning styles screening item received the version of the survey that included the essentialism items and the experiment. I made no predictions or hypotheses about important differences between those who chose 'Agree' and those who chose 'Strongly Agree'. In examining the descriptive statistics of the relevant variables, I saw a relatively even split between those who chose 'Agree' $(42 \%, n=49)$ and those who chose 'Strongly Agree' $(58 \%, n=69)$. However, I noticed a different distribution in levels of agreement among the participants who described experiencing the most conceptual change. Of those participants coded as "agreeing" or having a "changed mind", $85 \%(n=11)$ chose 'Agree' in the learning styles screening item, and only $15 \%$ ( $n$ $=2$ ) chose 'Strongly Agree'. This finding indicates that in addition to receiving a 
refutation text, level of initial agreement with the learning styles screening item may also be a contributing factor in conceptual change.

\section{Theme 3: Personal Experience is King}

Participants frequently pointed to their own personal experience as classroom teachers as the most convincing evidence for their beliefs about learning styles. Of the 22 participants who I coded as reporting no change in their beliefs about learning styles, 11 specifically mentioned their own classroom experiences as counterevidence to the texts. Participants described the importance of their own experiences regardless of their random assignment to receive a researcher or a teacher source. One participant who received a researcher as the source shared, "Just because an unknown researcher couldn't determine the differences in how students retained information doesn't discredit my years of experience differentiating." A participant who received a teacher as the source shared a similar sentiment, noting that the text "Didn't change my understanding of my own experience teaching kids."

Participants further demonstrated their reliance on their own experience and expertise in their reactions to the expertise of their randomly assigned source. A large group of participants $(n=33)$ reported that the source of the text had no impact on their beliefs. These responses were evenly reported by participants assigned to both teacher and researcher sources. One participant shared that the source meant "not much" to them as the information was coming "from teacher to teacher." Another participant who shared in that doubt stated, "That might have been their expertise from their classroom but they can hardly speak for all." Participants assigned to receive researcher sources were equally leery. One simply stated that in considering the evidence they "go more with experience" 
and another argued that "A study or two doesn't compare to 20 years of teaching expertise."

\section{Theme 4: In Shock and Awe (a Little Annoyed Too)}

For many participants, the information about the evidence against learning styles evoked an emotional response. "Amazed", "Intrigued", “Curious”, and "Amused” are among the many descriptors participants provided for their reactions. The word "surprised" alone came up in the responses of 16 different participants. This is an important finding as it indicates that for many participants, this study was the first time they had been exposed to evidence against the use of learning styles in the classroom. Some participants expressed surprise about the study findings (e.g., "I was surprised that the preferred learning style did not improve or decrease academic performance." and, "I was surprised to learn that there was no difference in results between students who learned in their preferred learning styles and students who did not."). Others directed their confusion at the clash between the evidence and what is promoted in their schools (e.g., "I was shocked because I thought if you received instruction in your preferred learning style you would do better with the subject matter.", "I was surprised to find that this information is going against what many universities teach.", "Surprising since it is often suggested to teachers that one way to meet students' needs is by utilizing different learning styles for instruction." and, "I am somewhat surprised because we are constantly told to differentiate and teach children in a variety of ways to meet the child's learning style.").

In addition to feelings of shock and surprise, some participants expressed more negative emotional reactions to the information. One participant reported feeling "torn" 
about what to believe going forward. They went on to say that they "want to believe that everyone...can excel more when matche[d] to their learning style, but I want to learn more so I know how to best teach my students." Another participant felt "frustrated that learning styles are still relied on and discussed so heavily in education and beyond." One went as far as to call the information in the text "nonsense", and questioned why any teacher would not "incorporate [learning styles] opportunities in their lessons."

\section{Theme 5: Skeptical of Research}

In addition to the skepticism participants shared about the researcher source, skepticism of the study mentioned in the text as well as of research more broadly was prevalent throughout responses. In some cases participants expressed skepticism of the research through general dismissiveness of the implications of the study. For example, one participant noted that "It was good to know that studies have been done, but I will always use different learning style methods when teaching..." In that statement they acknowledged the study but did not assign it any weight in their opinion formation. Several other participants reported similar lines of thinking, sharing that regardless of the outcomes of the study, their belief in the efficacy of learning styles remained the same (e.g., "I was just surprised about the outcome of the study. I still think it's important to cater to multiple learning styles.", "I do believe they came up with that conclusion. But I would need more information in order to change my beliefs on the matter.", "I mean it made me double think my answers, but I'm sure there are other studies that show differently. I can tell you right now I learn better when I am being active.", "I'm pretty surprised. I, myself, still feel that I learn best in my learning style.”). One participant even expressed that they "already knew" that there was no evidence to support learning styles, 
but that they still "believe that all students learn differently and this means that we need to learn how they learn and present the information in that way."

Some participants raised valid questions in their criticism of the description of the study in the text. For example, a few participants said they were curious about the sample size (e.g., "how many people were used?"), or if there were any existing conflicting studies (e.g., "I am wondering if this research is new \& these are new findings, or if this research is outdated, this being currently invalid[sic].", and "I have some questions about...whether there are other conflicting studies on this matter."). Both the refutation text and the expository text specifically stated that several groups of researchers have conducted multiple studies, all concluding that catering to student learning styles is ineffective in improving learning outcomes. However, several participants expressed the need for additional studies (e.g., "They're[sic] needs to be more studies done.”). The need for additional empirical evidence is particularly interesting, as none of the participants pointed to existing pro-learning styles research, indicating that empirical evidence is likely not what formed their belief in learning styles. Claims from participants directly comparing empirical evidence with anecdotal experience supports this notion (e.g., "Research can be flawed and in my experience what this particular researcher is claiming goes against my own personal experience." and, "I believe you can find research to support any opinion. I do what's best for my students, regardless of [the] article.”).

\section{Theme 6: I Knew It All Along}

Although most participants reported confidence in their original endorsement of learning styles, an interesting finding is that some participants reported a mis-match between their initially reported beliefs and their true beliefs. When I asked participants to 
share the extent to which the text affected their beliefs about learning styles, some participants admitted that they had a "gut feeling" that learning styles were not effective. This was a puzzling finding as these participants reported "Agreeing" or even "Strongly Agreeing" with the learning styles screening item. One participant explained that the information in the text "clarified a belief that I hold that students shouldn't be taught only in their particular learning style." Another participant shared a similar experience, noting that the text "confirmed what I thought/had heard, that learning styles aren't actually useful." Others touched on their awareness of the issues with learning styles research, with one saying that they "had a bit of prior knowledge" and another sharing that they, "already knew that learning styles were not a research-based practice", resulting in them feeling "validated by reading the text." One participant was especially straightforward and shared, "Honestly, it is how I felt before but I didn't think I could possibly be right. Reading the text helped me feel better about my thoughts."

\section{Theme 7: Misconceptions}

Participant responses not only shed light on their misconceptions about the usefulness of catering to learning styles, they also demonstrated misconceptions about the definition of a learning style and the predictions of the learning styles theories. One misconception was that catering to student learning styles is the same as differentiating. For example, one participant responded to the information in the text by stating that they "still believe that teachers need to differentiate their teaching to meet the student's needs." Another shared that they are questioning their beliefs because of "what I have been told in education classes about differentiation." Similarly, this participant argued that "If they do not perform better or worse, then why differentiate[?]". They went on to state that "it 
is always a good idea to mix things up in the classroom.", indicating that they may have been likening learning styles-based instruction to variety in activities.

Some participants who reported agreeing that teachers should match instruction with student learning styles later contradicted themselves with statements such as "I have seen children grow in my own room using different learning styles. I don't only present information in their preferred way..." Similarly, another participant stated that information in the text did not change their agreement with learning styles, then stated that they've "always felt students learned best through a variety of modes". The prediction of the learning styles theory is that each student has a preferred style, and that when that style is met, students learn the best. If the participants endorse the prediction of the theory, they cannot also claim to teach each student with multiple styles.

Participants veered from the predictions of the learning styles theories in other interesting ways as well. Some suggested that other factors mediate the effect of catering to learning styles such as "deeper meaning", or that it will be "easier for [students] to learn when their learning styles are addressed and matched." Together, these misconceptions suggest that although teachers are widely encouraged to use learning styles based instruction in their classrooms, they may not have received clear or consistent information about what exactly that means, or why it would be effective.

\section{Research Question 4}

I also analyzed the open-ended responses I presented to participants who did not endorse learning styles. This analysis provided answers to the final research question, "How did teachers who currently do not endorse a belief in learning styles form their conceptions about the phenomenon?" I uncovered three major themes, described in detail 
below. The majority of participants responded to the four open-ended questions. Question 1, "Describe your current beliefs about learning styles." had a $100 \%$ response rate $(\mathrm{n}=$ 23). Questions 2 and 3, "If applicable, describe how your beliefs about learning styles have ever been different than they are currently?", and "Describe the evidence against learning styles that you find most convincing and why." had a 91\% response rate ( $n=$ 21). Finally, Question 4, "The belief that learning is more effective when student materials match with their preferred learning styles is popular. Why do you believe educators so often hold this belief?" had a $96 \%$ response rate $(n=22)$.

\section{Theme 1: Most Teachers Who do not Currently Endorse Learning Styles did Endorse them Previously}

As predicted, participants who did not endorse learning styles were in the minority $(n=23)$. I asked these participants if their beliefs about learning styles had ever been different than they were at the time of the survey. Only four reported that their beliefs about learning styles had stayed the same over time. The majority of participants reported that there was a time when they did believe that catering to learning styles was effective in improving student learning. Participants often mentioned being taught about the importance of learning styles in their undergraduate teacher preparation courses (e.g., "In college I was taught that each student had a preferred learning style.", "In my undergrad studies I learned a lot about surveying students about their preferred style.", "I was taught in undergrad that multiple learning styles exist, and that kids should be taught based on which ones were their strongest." and, "I was taught in my teaching program about learning styles. I was required to submit lesson plans demonstrating how I was addressing learning styles.”). 
Additionally, participants also discussed how the learning styles myth extended into their teaching careers. One participant noted, "When I first started teaching, it was presented as a fact. So, without looking into it, I believed what I was told.” Another shared, "I initially bought into it as a novice teacher." Some participants also noted that the use of learning styles often dictated their instruction. One response read, "Before [researching] I believed learning styles were real and designed lessons around them." Similarly, another read, "I [used] to believe in learning styles. In fact a district I worked in wanted each of them planned for all the time."

Relatedly, when I asked participants why they believed that learning styles remained so popular among educators, many pointed to the fact that information about learning styles is directly taught and promoted both in teacher education and in professional developments. This was another major area of frustration for teachers who no longer endorsed the use of learning styles. One participant lamented, “...[W]e are taught this garbage in our PD days and in our education classes!" Another pointed to the promotion of learning styles theories by "gurus" as the primary reason for their popularity. A participant shared in this sentiment, labeling learning styles promoters as "snake oil salesmen." In addition to issues with those who stand to profit off of the use of learning styles, participants also took issue with how their fellow teachers approached the information. One participant urged educators to "think critically and thoughtfully reflect about pedagogical fads." Another added that teachers "tend to hold onto what they learn from college or in their beginning years of teaching."

\section{Theme 2: Exposure to Research Largely Informs Teachers' Conceptions.}


In their explanations of how their beliefs about learning styles have changed, several participants discussed the role of research (e.g., “...after conducting research, and reviewing existing literature, I realized that [learning styles are] simply not a predictor of success." and "Before hearing research regarding this, I believed in the idea of each of us having a learning style.”). One participant specifically cited having learning styles debunked in a classroom, "I'd heard about learning styles, but in my teacher ed program professors talked about reasons why they were not [important].” Additionally, when I asked participants to describe their current beliefs about learning styles, they frequently discussed the lack of evidence (e.g., "Students may have a preferred learning style, but the research I've seen doesn't support that they actually learn better.", "Learning styles are not supported by cognitive science research.", and "There is no RESEARCH based, scientifically backed evidence to conclude learning styles actually exist/have a significant impact on learning."). Some participants even marked their current beliefs with annoyance about the continued popularity of learning styles, despite the lack of evidence. For example, one participant described learning styles as "a vampire [that] continue[s] to live on, even in graduate school". Another called learning styles a "sparsely supported panacea for educators."

Finally, when I asked participants about the evidence against learning styles that they found most convincing, they pointed most frequently to results of empirical research (e.g., "In the last few years scholarly articles and journalism have presented a wave of pieces aimed at debunking some of this.", "The various published studies that show that "learning styles" is a myth." and, "Studies do not show improved performance based on modality. Performance results and quality research is most convincing to me."). Some 
participants noted not only the evidence against learning styles, but the absence of evidence for them. One teacher described themselves as "most compelled by the LACK of supporting evidence more than any singular counterpoint." Another echoed by noting that "it doesn't appear there are studies that support learning styles."

Although research was the primary source of evidence participants found convincing, they also often reported feeling convinced by their classroom experience and logical reasoning about learning styles. One participant mentioned the assessment scores of their students, "They don't score higher if they learn with their preferred style; they don't score lower when taught in a non-preferred style." Others acknowledge that their evidence is anecdotal (e.g., "Nothing specific to cite, just anecdotal evidence." and "Anecdotal evidence based on my experiences with hundreds of students."). Finally, some participants pointed to problems with the reasoning behind learning styles as evidence. One argued that the way students should learn is specific to the subject and thus teaching should be "based more on content." Another discussed the more universal benefits to some teaching strategies that are often confounded with arguments for learning styles, "all students benefit from dual coding - not just the ones that "prefer" one style to another."

\section{Theme 3: Acknowledging Preferences}

In their descriptions of their beliefs about learning styles, participants who did not endorse the efficacy of catering to learning styles in the classroom frequently acknowledged that students may have preferences for modes of learning. However, an important difference between participants who do and do not endorse learning styles is the belief about how catering to those preferences affects learning. I coded 11 participants 
as specifically discussing that students having a preference does not mean that they will learn better in that way (e.g., "I'm just not sure...that these learning styles are the only way they can learn, or necessarily even the best.", and "People can have a preferred way of learning but it is not the only way they can learn."). In contrast, participants who endorse learning styles point to differences in their students as evidence for learning styles theory (e.g., "I think that some people really do have an affinity for certain styles of learning."), often inaccurately coupling the use of learning styles with general differentiation (e.g.," I still believe that teachers need to differentiate their teaching to meet the student's needs. 


\section{DISCUSSION}

The belief that teachers should cater their instruction to match student learning styles is widespread (e.g., Praxis, 2019; Toppo, 2019). Pre-service teachers are explicitly taught to use learning styles-based instruction, and the method is continually reinforced even for educators at the university level (e.g., University of Massachusetts Dartmouth, 2019). There is no good empirical evidence that students learn more effectively when teachers cater to their learning styles, instead there is a wealth of evidence to the contrary (e.g., Pashler et al., 2008). Researchers have made many attempts at combating the popularity of learning styles (e.g., Kirschner, 2017; Willingham et al., 2015). However, the majority of these attempts at changing teacher conceptions operate within the "cold" paradigm of conceptual change, and do not tap into the motivational and subjective factors that contribute to conceptual change, also known as the "hot" paradigm (Pintrich et al., 1993).

The myth that students learn best when presented information in their preferred learning style remains popular, even despite funded informational materials that the belief has been debunked by the U.S Department of Education (Smithsonian, 2017; Toppo, 2019). The use of learning styles-based instruction has the potential to impede student learning (e.g., Kirschner, 2017), as well as put unnecessary stress on teachers (e.g., Rohrer \& Pashler, 2012). Additionally, it contributes to the rift between education research and education practice. Thus, as a field, we need to improve our conceptual 
change strategies by operating from the "hot" paradigm and tapping into teachers' motivational and subjective beliefs.

Few researchers have investigated which conceptual change strategies have been effective in changing teachers' beliefs about learning styles. This is an important gap to fill, as that information will help in shaping conceptual change strategies moving forward. Additionally, few researchers have examined possible differences in learning styles beliefs among teachers (Nancekivell et al., 2019). Moreover, the majority of the research in debunking the myth about learning styles consists of systematic or literature reviews of the current evidence (e.g., Coffield et al., 2004; Pashler et al., 2008), there are few studies that use quantitative methodology to examine learning styles beliefs (e.g., Nancekivell et al., 2019; Newton \& Miah, 2017), and none that use a qualitative approach to uncover beliefs about learning styles from the teachers themselves.

In addition to contributing to learning styles research, this study also contributes to our theoretical understanding of conceptual change, more specifically the Cognitive Reconstruction of Knowledge Model (CRKM; Dole \& Sinatra, 1998). This model aligns with the "hot" conceptual change paradigm by integrating the role of subjective and motivational factors in the conceptual change process. In this current study I used the CRKM as the theoretical roadmap to address conceptual change in my participants. The results of the study provide some evidence for the CRKM and the "hot" paradigm more broadly.

I used the CRKM to investigate differences in conceptual change experiences for teachers through comparison between the "hot" (refutation text) and "cold" (expository text) paradigms. I also added to the literature on differences in teacher beliefs about 
learning styles by identifying participants' level of essentialism and examining how those beliefs affected their conceptual change. I asked participants who did not endorse learning styles at the time of the survey to respond to open-ended questions about their beliefs, and how those beliefs changed over time and in response to information about learning styles. I asked participants who did endorse learning styles to complete a scale identifying their level of essentialist beliefs, and then randomly assigned them to receive either an expository or refutation text, and either a teacher or researcher source.

I had four primary research questions. I sought to determine if teachers who endorsed learning styles experienced greater conceptual change after reading an expository text or a refutation text, and if that degree of conceptual change was affected by both the source of the text and the level of essentialism. I included the grade level taught by participants in the model as a control, based on some literature that suggests differences in beliefs between teachers of young students and older students (e.g., Nancekivell et al., 2019). I hypothesized that conceptual change would be stronger for those assigned a refutation text compared to an expository text, for those assigned a teacher source compared to a researcher source, and for those with lower levels of essentialism compared to higher levels. I hypothesized a three way interaction wherein participants who received a refutation text from a teacher source and identified as less essentialist would experience the greatest conceptual change. To capture information about that conceptual change experience, I used open-ended questions to gather qualitative data from participants. I hypothesized that the qualitative data would corroborate the quantitative results, with participants randomly assigned to receive the refutation text with a teacher source, and who identified as less essentialist describing the 
strongest conceptual change. Finally, I wanted to uncover how teachers who did not endorse learning styles formed their current beliefs. I hypothesized that few participants would report not endorsing learning styles, and that those who did, would report experience with having their beliefs debunked.

The results from the quantitative analysis revealed that the model did not significantly predict conceptual change about learning styles. Participants' conceptual change scores were high for those who received the refutation text compared to the expository text, for those who received a researcher source compared to the teacher source, and for those who had lower levels of essentialism compared to higher levels of essentialism. However, the differences were not significant. The interaction effect was such that the negative relationship between conceptual change scores and essentialism scores was strongest for participants randomly assigned to receive the refutation text from the researcher source, which I did not predict.

I revealed seven major themes through the qualitative analysis of the responses from participants who endorsed learning styles. I found that although few participants reported a complete change in their beliefs about learning styles, a large proportion did report some level of analysis of their beliefs. I found little evidence of a pattern of reports of conceptual change for any combination of level of essentialism, text type, and source type. The types of responses were distributed evenly across experimental groups in all cases but one. Those who reported experiencing the strongest conceptual change were more likely to have received a refutation text. Participants reported a stronger trust in their own experiences as teachers than in a teacher source or a researcher source. Reports of surprise and intrigue were common across both refutation and expository text 
conditions. The qualitative analyses also revealed that in addition to the inaccurate belief that catering to learning styles improves learning, teachers also have several misconceptions about the prediction of the learning styles theories, as well as the role of empirical research in disproving those theories. In the literature review I discussed the social reinforcement of learning styles among educators. I found that this contributed to the difficulty in changing teachers' beliefs about learning styles, as the overwhelming majority of educators and education entities support and promote the use of learning styles based instruction.

In my qualitative analysis of the responses from participants who did not endorse learning styles, I found three major themes. Although there were few participants in this group, I found that nearly all of them reported that at one point, they did believe that catering to student learning styles was effective in improving learning. The participants shared that their belief in learning styles came from direct instruction, often during their teaching education or in professional developments. The participant responses also indicated that the primary reason for their conceptual change was more instruction - this time involving empirical evidence and debunking. Participants who did not endorse learning styles frequently acknowledged the existence of preferences in their students. The important difference was that those who did not endorse learning styles reported an understanding that having a preference for an activity does not indicate anything about the student's ability to learn.

Although the model did not significantly predict participants' conceptual change, the results of this study still provide some evidence for the CRKM and the "hot" paradigm of conceptual change. Motivational and subject factors played a large role in 
the conceptual change experience of the participants. This finding adds to recommendations from other researchers (e.g., Heddy et al., 2017; Pintrich et al., 1993; Sinatra et al., 2014) who previously highlighted the need for research in conceptual change to take these influential factors into consideration. More specifically, the results from this study support the different factors of motivation for conceptual change outlined in the CRKM. The model predicts that learners who feel satisfied with their current beliefs will be less likely to engage in conceptual change than those who feel dissatisfied (Dole \& Sinatra, 1998). In this study, I found that participants who did not engage in conceptual change consistently report satisfaction with their beliefs and those who did engage in conceptual change reported feeling that their beliefs did not fully satisfy their questions and understanding of learning styles. This finding is in line with what other researchers have reported about the effect of dissatisfaction in current beliefs on conceptual change (e.g., Gess-Newsome et al., 2003; Hilpert \& Brem, 2013).

I also found evidence to support the 'Social Context' factor. Several teachers reported endorsing learning styles at the start of the survey, but then in describing their beliefs, reported that they had in fact, always had doubts about the use of learning styles. This finding illustrates the difficulty many experience in reporting a belief that goes against an established norm (Asch, 1955, 1956). Participants also specifically discussed that not endorsing learning styles would put them in direct opposition to administration (e.g., "Administrators latch onto educational buzzwords, like learning styles, and then expect teachers to utilize the concept."). In addition to the predictions of the CRKM, this finding aligns with previous research on social context in conceptual change (e.g., Linn \& 
Songer, 1991; Liu, 2004), and may illustrate that teachers feel some level of obligation or social pressure to endorse learning styles.

In addition to the evidence for the 'Motivation' component, this research also supports the role of the learner's existing conceptions, as outlined in the CRKM. Important information about the strength, coherence, and commitment of the learner's existing conceptions proved relevant in their conceptual change process. From an outside perspective, the participant's descriptions of their beliefs do not appear strong or coherent, as they are neither well-formed, nor do they leave no loose ends. What appears to be the most influential on their conceptions is their commitment to those beliefs. One example of participants' commitment to their conceptions is their initial agreement with the learning styles screener. Those who reported experiencing conceptual change had a disproportionately large number of participants who chose 'Agree' instead of 'Strongly Agree' as compared to the total portion of the sample. This is an ad-hoc finding that indicates that there may be important differences in commitment to the belief among those who endorse learning styles, and that those differences may impact conceptual change.

Commitment to a belief transcends both strength and coherence such that if a learner is committed to holding a belief, it does not matter if the belief is illogical or weakly supported by evidence (Dole \& Sinatra, 1998). Teachers' beliefs in learning styles appear to be quite personal, with several participants discussing their own learning styles and experiences as learners in their responses. This type of belief is likely different in non-trivial ways to other beliefs commonly examined in conceptual change research, such as Newtonian physics (e.g., Linnenbrink \& Pintrich, 2002). Teachers' commitment 
to their belief in learning styles may indicate that for many teachers, this belief is closer to beliefs like creationism. As such, the teachers' beliefs in this study may be affected by what Dole \& Sinatra (1998) refer to as a "need to believe", which occurs in cases where individuals are highly committed to their beliefs.

This high level of commitment is again illustrated through the lack of coherence and strength in participants' explanations of learning styles. In addition to holding the inaccurate belief that catering to learning styles improves learning, teachers also have several misconceptions about the prediction of the learning styles theories, as well as the role of empirical research in disproving those theories. For example, several participants provided contradicting statements about their belief in the importance of learning styles and their practice of catering to learning styles in their classroom. This finding also indicates that there may be variations in teachers' understanding of the definition of learning styles. This is particularly important in conceptual change research as it is more difficult to engage teachers in conceptual change if we do not correctly identify and then address their misconceptions. The texts I used in this study address the misconception that catering to learning styles improves student learning outcomes. However, if teachers have an additional misconception that catering to learning styles is synonymous with differentiating, the text should also address that misconception to promote effective conceptual change.

In addition to the misconceptions about the learning styles theories, teachers also have misconceptions about empirical research. Teacher education programs and teacher professional developments do not typically include instruction on data analysis and research methods (Green \& Blankenship, 2013), and thus, generally speaking, teachers 
have limited knowledge about effectively discerning between good and poor sources of evidence. This is an issue for several reasons and is largely outside of teachers' control. However, for this research specifically, it is difficult to use evidence from the literature to convince teachers that catering to learning styles is ineffective without first addressing their misconceptions about that evidence. A conceptual change text centered around the explanation of research will be less convincing for a teacher who believes that anecdotal experiences and empirical research are comparable sources. Moreover, if teachers are motivated by the "need to believe", then providing additional evidence and logical explanation may not be effective.

Finally, in this research I provide support for the factors in the 'Message' component of the CRKM. There were no reports from participants that the information in the texts was not comprehensible or coherent, two key factors in the 'Message' component. Participant responses indicated that they understood the stance being communicated through the text, however they did not typically agree with it. The factor I attempted to manipulate between expository and refutation texts was the degree to which the text was rhetorically compelling. Messages that are more rhetorically compelling are typically more convincing (Dole \& Sinatra, 1998). As I mentioned, I found that surprise and intrigue were common reactions across both text conditions. This finding went contrary to my prediction that a refutation text would in part be more rhetorically compelling due to its promotion of situational interest and engagement. However, the pattern for participants who reported the greatest conceptual change having received a refutation text provides some evidence that receiving a refutation text may contribute to greater conceptual change. 
Overall, participants did not appear to perceive the message in the texts as plausible enough to change their beliefs. Plausibility refers to the learner's belief that the information could reasonably be true (Dole \& Sinatra, 1998). Plausibility judgements are estimates of truthfulness based upon comparisons of available data to an alternative explanation (Sinatra \& Lombardi, 2020). Similar to conceptual change as a whole, judgements about the plausibility of a statement can be highly subjective and based upon motivational factors (Lombardi et al., 2016). A participant may actively understand that the evidence provided in the text is scientifically sound, yet still choose to compare that evidence with their own classroom experiences, and deem the latter a more plausible explanation for the phenomena (Lombardi et al., 2016). As evidenced by the results of the study, a lack of plausibility in the message negatively contributed to conceptual change.

\section{Implications}

The current study has important implications for both teacher education and research in the conceptual change of learning styles beliefs. The continued prevalence of the belief that teachers should cater instruction to student learning styles to improve learning is evidence that we are doing a massive disservice to both teachers and students in our teacher education programs and professional developments. In addition to the disservice of heavily promoting a theory that is entirely lacking in support from the evidence base, we also continually disserve teachers and students by not requiring that teachers receive instruction in data analysis and research methods. Teacher licensure exams do not assess these skills (Praxis, 2019). Instead the onus is often on teachers to seek out their own research education (DeMott Painter, 2019). Additionally and in line 
with recommendations from Sinatra and Lombardi (2020), students should also receive instruction in evaluating plausibility judgements. Substantive changes in those areas may improve the rate at which future pre-service and in-service teachers endorse learning styles.

Participant responses did not appear to differ based upon their level of essentialism. However, the results did indicate that there are differences in beliefs and misconceptions among those who endorse learning styles. In order to effectively engage teachers in conceptual change, researchers need a clear understanding of participants' existing conceptions (e.g., Cordova et al., 2014; Hewson \& Hewson, 1983). Researchers have only recently begun to examine different types of learning styles beliefs (Nancekivell et al., 2019). This will likely be an important area to address going forward. Although evidence for stronger conceptual change is ideal, I found a generally positive trend of participants beginning to question their beliefs after reading the texts. Few participants reported not endorsing learning styles, but nearly all of them reported that at one point, they did believe that catering to student learning styles was effective in improving learning. This finding indicates that these participants had experienced effective and lasting conceptual change, which bodes well for participants who still currently endorse learning styles. The results from this study highlight the difficulty in changing these beliefs, but they also highlight that it is possible.

Relatedly, the majority of research articles about debunking learning styles are only accessible for other researchers. As described in the discussion, this research provides support for the use of the "hot" paradigm in conceptual change, as well as for the use of the CRKM as a theoretical framework for examining and understanding 
conceptual change. To effectively use the paradigm and model, researchers need to begin purposefully addressing their audience so that the teachers can begin to access this important information. Additionally, in creation of their arguments, researchers should acknowledge and incorporate the role of motivational and subjective factors. 


\section{LIMITATIONS}

Based on the recommended sample size from the a priori power analysis, the quantitative analysis in this study was underpowered, with a sample size around 10 times smaller than ideal. The results of the multiple regression led to failure to reject the null hypothesis. However, because of the low power, I cannot confidently state that the failure to reject the null was a reflection of the true effect in the population, or if I committed a type 2 error.

Additionally, I did not pilot test the refutation and expository texts. In addition to piloting, I could improve the texts with feedback from content experts. The responses from participants revealed that they held misconceptions about learning styles beyond what was addressed in the refutation and expository texts. A more thorough identification of the types of misconceptions teachers have about learning styles would enable researchers to identify those misconceptions and likely improve the effectiveness of the texts.

Another possible limitation was in the wording that indicated the source of the message to participants. The wording was brief, it simply stated that the text was written by either a teacher or a researcher. There were a few participants who reported not recalling the author of the text, which may indicate that the information was not made clear enough. Additional content and construct validity evidence for the texts would be helpful in decreasing potential for error in the analyses. Similarly, the three items used to 
measure conceptual change could benefit from additional scale development, and reliability and validity evidence. 


\section{FUTURE DIRECTIONS}

Based on the results from this study, I have identified several avenues for future

research. Firstly, the texts I used in this study addressed the misconception that catering instruction to students' learning styles improves learning outcomes. The results of the analysis revealed that the participants held many additional misconceptions about learning styles. In future research it may be fruitful to first identify the types of misconceptions held by teachers, and then create a conceptual change text that addresses all of those misconceptions.

The results of the analyses also revealed that teachers' beliefs in learning styles may be affected by what Dole and Sinatra (1998) refer to as the "need to believe". When individuals "need to believe", the coherence and strength of their conceptions are less convincing. Future research in changing teachers' conceptions about learning styles should explore this possibility, and further examine the nature of teachers' existing conceptions about learning styles, particularly their commitment to their beliefs.

Additionally, there is currently no measure for motivation for conceptual change that aligns with the factors of the 'Motivation' component of the CRKM. I am currently working on developing such a measure. Motivation is a primary part of the "hot" paradigm for conceptual change (Pintrich et al., 1993) and future research using the CRKM to examine conceptual change would benefit from a validated measure that operationalizes the construct. More specifically, future researchers would be able to use a 
measure of motivation for conceptual change to more accurately predict conceptual change. 


\section{CONCLUSION}

More than 15 years have passed since the publication of one of the most renowned reviews of learning styles literature (Coffield et al., 2004). Despite the conclusions of this review and the many publications that followed, the myth that teachers should cater instruction to meet student learning styles still appears to be the dominant belief among educators. This current study addresses the latest research on "hot" conceptual change, along with the very recent call for researchers to examine differences in teachers' learning styles beliefs. The results underscore the importance of acknowledging the role of subjective and motivational factors in the conceptual change process.

Teachers who endorse learning styles are not easily swayed by exposure to conceptual change texts, and report feeling personally connected and motivated to keep their beliefs. However, the results also reveal that conceptual change about learning styles is possible among teachers, and that for those who no longer endorse learning styles, an understanding of the empirical evidence was a key factor in their conceptual change experience. Furthermore, this current study contributes the first qualitative phenomenological inquiry in debunking the myth of learning styles among teachers. The combined ten major themes illustrate the fruitfulness in analyzing teachers' descriptions and experiences of the conceptual change process. Finally, teachers and students deserve to receive instruction that is rooted in evidence. In the discussion and implications 
sections of this manuscript I highlight the ways that pre-service teacher education and in-service professional developments can provide educators with the tools to digest and discern evidence. To quote a participant, learning styles are a "a vampire [that] continue[s] to live on." This study furthers the efforts of other researchers to move the needle towards putting an end to the learning styles myth. 


\section{REFERENCES}

Ariasi, N., Hyönä, J., Kaakinen, J. K., \& Mason, L. (2017). An eye-movement analysis of the refutation effect in reading science text. Journal of Computer Assisted Learning, 33(3), 202-221. https://doi.org/10.1111/jcal.12151

Asch, S. E. (1955). Opinions and social pressure. Scientific American, 193(5), 31-35. https://doi-org.echo.louisville.edu/10.1038/scientificamerican1155-31

Asch, S. E. (1956). Studies of independence and conformity: I. A minority of one against a unanimous majority. Psychological monographs: General and applied, 70(9), 1. https://doi-org.echo.louisville.edu/10.1037/h0093718

Beker, K., Kim, J., Van Boekel, M., van den Broek, P., \& Kendeou, P. (2019). Refutation texts enhance spontaneous transfer of knowledge. Contemporary Educational Psychology, 56(1), 67-78. https://doiorg.echo.louisville.edu/10.1016/j.cedpsych.2018.11.004

Bjork, E. L., \& Bjork, R. A. (2011). Making things hard on yourself, but in a good way: Creating desirable difficulties to enhance learning. In M. A. Gernsbacher, R. W. Pew, L. M. Hough, \& J. R. Pomerantz (Eds.), Psychology and the real world: Essays illustrating fundamental contributions to society. (pp. 56-64). New York, NY: Worth Publishers.

Braio, A., Beasley, T. M., Dunn, R., Quinn, P., \& Buchanan, K. (1997). Incremental implementation of learning style strategies among urban low achievers. The 
Journal of Educational Research, 91(1), 15-25.

https://doi.org/10.1080/00220679709597516

Broughton, S. H., Sinatra, G. M., \& Reynolds, R. E. (2010). The nature of the refutation text effect: An investigation of attention allocation. The Journal of Educational Research, 103, 407-423. https://doi.org/10.1080/00220670903383101

Brown, P. C., Roediger III, H. L., \& McDaniel, M. A. (2014). Make it stick. Harvard University Press.

Chou, M. (2017). English language education in formal and cram school contexts: An analysis of listening strategy and learning style. Education 3-13, 45(4), 419-436. https://doi-org.echo.louisville.edu/10.1080/03004279.2015.1103768

Cicco, G. (2009). Online versus in-class courses: Learning-style assessment as an advisement tool. International Journal on E-Learning, 8(2), 161-173. https://www.learntechlib.org/p/25302/

Coffield, F., Moseley, D., Hall, E., \& Ecclestone, K. (2004). Learning styles and pedagogy in post-16 learning: A systematic and critical review. http://evidence.thinkportal.org/handle/123456789/62

Cordova, J. R., Sinatra, G. M., Jones, S. H., Taasoobshirazi, G., \& Lombardi, D. (2014). Confidence in prior knowledge, self-efficacy, interest and prior knowledge: Influences on conceptual change. Contemporary Educational Psychology, 39(2), 164-174. https://doi-org.echo.louisville.edu/10.1016/j.cedpsych.2014.03.006 Creswell, J. W. (2017). Qualitative inquiry \& research design: Choosing among five approaches (4th ed.). Thousand Oaks: CA: Sage Publications, Inc. 
Creswell, J. W., \& Miller, D. L. (2000). Determining validity in qualitative inquiry. Theory Into Practice, 39(3), 124-130. https://doi.org/10.1207/s15430421tip3903_2

Davis, J. K. (1975). Conditional concept learning and cognitive style. Perceptual and Motor Skills, 40(3), 859-862. https://doiorg.echo.louisville.edu/10.2466/pms.1975.40.3.859

Dawson, K., \& Dana, N. F. (2007). When curriculum-based, technology-enhanced field experiences and teacher inquiry coalesce: An opportunity for conceptual change? British Journal of Educational Technology, 38(4), 656-667. https://doi.org/10.1111/j.1467-8535.2006.00648.x

Demott Painter. (2019). Teacher Research Could Change Your Practice. http://www.nea.org/tools/17289.htm

Diakidoy, I.-A. N., Kendeou, P., \& Ioannides, C. (2003). Reading about energy: The effects of text structure in science learning and conceptual change. Contemporary Educational Psychology, 28(3), 335-356. https://doi.org/10.1016/S0361476X(02)00039-5

Diakidoy, I.-A. N., Mouskounti, T., \& Ioannides, C. (2011). Comprehension and learning from refutation and expository texts. Reading Research Quarterly, 46(1), 22-38. https://doi.org/10.1598/RRQ.46.1.2

Dole, J. A., \& Sinatra, G. M. (1998). Reconceptualizing change in the cognitive construction of knowledge. Educational Psychologist, 33(2-3), 109-128. https://doi-org.echo.louisville.edu/10.1207/s15326985ep3302\&3_5 
Drexel University School of Education. (2019). Lesson Plan Guidelines for Student Teachers. https://drexel.edu/soe/resources/student-teaching/how-to-write-alesson-plan/

Emmons, N. A., \& Kelemen, D. A. (2015). Young children's acceptance of withinspecies variation: Implications for essentialism and teaching evolution. Journal of Experimental Child Psychology, 139(11), 148-160. https://doiorg.echo.louisville.edu/10.1016/j.jecp.2015.05.011

Fine, C., \& Duke, R. (2015). Expanding the role of gender essentialism in the single-sex education debate: A commentary on Liben. Sex Roles: A Journal of Research, 72(9-10), 427-433. https://doi-org.echo.louisville.edu/10.1007/s11199-015-0474-

$\underline{0}$

Gelman, S. A. (2003). The essential child: Origins of essentialism in everyday thought. Oxford University Press. https://doiorg.echo.louisville.edu/10.1093/acprof:oso/9780195154061.001.0001

Gelman, S. A. (2013). Artifacts and essentialism. Review of Philosophy and Psychology, 4(3), 449-463. https://doi-org.echo.louisville.edu/10.1007/s13164-013-0142-7

Gowaty, P. A. (2018). Biological essentialism, gender, true belief, confirmation biases, and skepticism. In C. B. Travis, J. W. White, A. Rutherford, W. S. Williams, S. L. Cook, \& K. F. Wyche (Eds.), APA handbook of the psychology of women: History, theory, and battlegrounds., Vol. 1. (pp. 145-164). Washington, DC: American Psychological Association. https://doiorg.echo.louisville.edu/10.1037/0000059-008 
Green, J. L., \& Blankenship, E. E. (2013). Primarily statistics: Developing an introductory statistics course for pre-service elementary teachers. Journal of Statistics Education, 21(3). https://doi.org/10.1080/10691898.2013.11889683

Gutierez, S. B., \& Kim, H.-B. (2017). Becoming teacher-researchers: Teachers' reflections on collaborative professional development. Educational Research, 59(4), 444-459. https://doi.org/10.1080/00131881.2017.1347051

Guzzetti, B. J., Snyder, T. E., \& Glass, G. V. (1992). Promoting conceptual change in science: Can texts be used effectively? Journal of reading, 35(8), 642-649. https://www.jstor.org/stable/40032156

Heddy, B. C., Danielson, R. W., Sinatra, G. M., \& Graham, J. (2017). Modifying knowledge, emotions, and attitudes regarding genetically modified foods. Journal of Experimental Education, 85(3), 513-533. https://doiorg.echo.louisville.edu/10.1080/00220973.2016.1260523

Heiphetz, L. (2019). Moral essentialism and generosity among children and adults. Journal of Experimental Psychology: General, 148(12), 2077-2090. https://doiorg.echo.louisville.edu/10.1037/xge0000587.supp (Supplemental)

Hewson, M. G., \& Hewson, P. W. (1983). Effect of instruction using students' prior knowledge and conceptual change strategies on science learning. Journal of Research in Science Teaching, 20(8), 731-743. https://doiorg.echo.louisville.edu/10.1002/tea.3660200804

Hilpert, J. C., \& Brem, S. K. (2013). Dissatisfaction and engagement as motivators of conceptual change in a naturalistic internet-based search about HPV. Electronic 
Journal of Research in Educational Psychology, 11(2), 285-310.

https://doi.org/10.14204/ejrep.30.12113

Hoffman, B., \& Nadelson, L. (2010). Motivational engagement and video gaming: A mixed methods study. Educational Technology Research and Development, 58(3), 245-270. https://doi-org.echo.louisville.edu/10.1007/s11423-009-9134-9

Huertas, A., López, O., \& Sanabria, L. (2017). Influence of a metacognitive scaffolding for information search in B-learning courses on learning achievement and its relationship with cognitive and learning style. Journal of Educational Computing Research, 55(2), 147-171. https://doi-

org.echo.louisville.edu/10.1177/0735633116656634

Hynd, C. R. (2001). Refutational texts and the change process. International Journal of Educational Research, 35(7-8), 699-714. https://doi.org/10.1016/S08830355(02)00010-1

Jones, S. H., Johnson, M. L., \& Campbell, B. D. (2015). Hot factors for a cold topic: Examining the role of task-value, attention allocation, and engagement on conceptual change. Contemporary Educational Psychology, 42(3), 62-70. https://doi.org/10.1016/j.cedpsych.2015.04.004

Kholodnaya, M. A. (1996). Cognitive style as the psychological concept: Individual preferences vs specific kind of faculties. Psikhologicheskiy Zhurnal, 17(1), 61-69.

Kirschner, P. A. (2017). Stop propagating the learning styles myth. Computers \& Education, 106(1), 166-171. https://doi-org/10.1016/j.compedu.2016.12.006

Kolb, D. A. (1971). Individual learning styles and the learning process. MIT. 
Kolb, D. A., Boyatzis, R. E., \& Mainemelis, C. (2001). Experiential learning theory: Previous research and new directions. In R. J. Sternberg \& L. Zhang (Eds.), Perspectives on thinking, learning, and cognitive styles.(pp. 227-247). Lawrence Erlbaum Associates Publishers.

Linn, M. C., \& Songer, N. B. (1991). Cognitive and conceptual change in adolescence. American Journal of Education, 99(4), 379-417. https://doiorg.echo.louisville.edu/10.1086/443991

Linnenbrink, E. A., \& Pintrich, P. R. (2002). The role of motivational beliefs in conceptual change. In Reconsidering conceptual change: Issues in theory and practice (pp. 115-135). Springer, Dordrecht.

Linnenbrink-Garcia, L., Pugh, K. J., Koskey, K. L. K., \& Stewart, V. C. (2012). Developing conceptual understanding of natural selection: The role of interest, efficacy, and basic prior knowledge. Journal of Experimental Education, 80(1), 45-68. https://doi.org/10.1080/00220973.2011.559491

Liu, X. (2004). Using concept mapping for assessing and promoting relational conceptual change in science. Science Education, 88(3), 373-396. https://doiorg.echo.louisville.edu/10.1002/sce.10127

Lu, T., \& Yang, X. (2018). Effects of the visual/verbal learning style on concentration and achievement in mobile learning. Eurasia Journal of Mathematics, Science \& Technology Education, 14(5), 1719-1729. https://doiorg.echo.louisville.edu/10.29333/ejmste/85110 
Lombardi, D., Nussbaum, E. M., \& Sinatra, G. M. (2016). Plausibility judgments in conceptual change and epistemic cognition. Educational Psychologist, 51(1), 3556. doi:10.1080/00461520.2015.1113134

Mason, L., Gava, M., \& Boldrin, A. (2008). On warm conceptual change: The interplay of text, epistemological beliefs, and topic interest. Journal of Educational Psychology, 100(2), 291-309. https://doi-org.echo.louisville.edu/10.1037/00220663.100 .2 .291

McDevitt, T. M., \& Ormrod, J. E. (2008). Fostering conceptual change about child development in prospective teachers and other college students. Child Development Perspectives, 2(2), 85-91. https://doi.org/10.1111/j.17508606.2008.00045.x

Nancekivell, S. E., Shah, P., \& Gelman, S. A. (2020). Maybe they're born with it, or maybe it's experience: Toward a deeper understanding of the learning style myth. Journal of Educational Psychology, 112(2), 221-235. https://doiorg.echo.louisville.edu/10.1037/edu0000366

Newton, P. M. (2015). The Learning Styles myth is thriving in higher education. Frontiers in Psychology, 6(1). doi: 10.3389/fpsyg.2015.01908

Newton, P. M., \& Miah, M. (2017). Evidence-based higher education-Is the learning styles 'myth' important? Frontiers in Psychology, 8(1). doi: 10.3389/fpsyg.2017.00444

O'Neil, J. (1990). Making sense of style. Educational Leadership, 48(2), 4-9. https://eric.ed.gov/?id=EJ416419 
Pashler, H., McDaniel, M., Rohrer, D., \& Bjork, R. (2008). Learning styles: Concepts and evidence. Psychological Science in the Public Interest, 9(3), 105-119. https://web-a-ebscohostcom.echo.louisville.edu/ehost/pdfviewer/pdfviewer?vid=98\&sid=1fa44651-186d4fad-933d-3edbd0e5de7d\%40sessionmgr4007

Pence, Z. A., \& Snyder, K. E. (2017). Instruction without learning styles: Possibilities and promise. Teaching for High Potential, 11(1), 1,17-18. https://www.researchgate.net/profile/Kate_Snyder2/publication/313115339_Instru ction_without_learning_styles_Possibilities_and_promise/links/5890ba71458515a eac92c9fc/Instruction-without-learning-styles-Possibilities-and-promise.pdf

Pintrich, P. R., Marx, R. W., \& Boyle, R. A. (1993). Beyond cold conceptual change: The role of motivational beliefs and classroom contextual factors in the process of conceptual change. Review of Educational Research, 63(2), 167-199. http://dx.doi.org.echo.louisville.edu/10.2307/1170472

Praxis. (2019). Praxis Principles of Learning and Teaching: Grades K-6. Praxis Principles of Learning and Teaching: Grades K-6. ETS.

Prinz, A., Golke, S., \& Wittwer, J. (2019). Refutation texts compensate for detrimental effects of misconceptions on comprehension and metacomprehension accuracy and support transfer. Journal of Educational Psychology, 111(6), 957-981. https://doi.org/10.1037/edu0000329

Ranellucci, J., Muis, K. R., Duffy, M., Wang, X., Sampasivam, L., \& Franco, G. M. (2013). To master or perform? Exploring relations between achievement goals and conceptual change learning. British Journal of Educational Psychology, 
83(3), 431-451. https://doi-org.echo.louisville.edu/10.1111/j.20448279.2012.02072.x

Räty, H., Mononen, N., \& Pykäläinen, E. (2017). Essentialism and social representations of intelligence. Social Psychology of Education: An International Journal, 20(4), 915-927. https://doi-org.echo.louisville.edu/10.1007/s11218-017-9399-5

Reeves, J., Turner, E., Morris, B., \& Forde, C. (2005). Changing their minds: The social dynamics of school leaders' learning. Cambridge Journal of Education, 35(2), 253-273. https://doi.org/10.1080/03057640500147219

Riener, C., \& Willingham, D. (2010). The myth of learning styles. Change: The Magazine of Higher Learning, 42(5), 32-35. https://doi.org/10.1080/00091383.2010.503139

Reis-Jorge, J. (2007). Teachers' conceptions of teacher-research and self-perceptions as enquiring practitioners-A longitudinal case study. Teaching and Teacher Education, 23(4), 402-417. https://doiorg.echo.louisville.edu/10.1016/j.tate.2006.12.007

Rhodes, M., \& Mandalaywala, T. M. (2017). The development and developmental consequences of social essentialism. WIREs Cognitive Science, 8(4). https://doiorg.echo.louisville.edu/10.1002/wcs.1437

Rohrer, D., \& Pashler, H. (2012). Learning styles: Where's the evidence? Medical Education, 46(7), 634-635. https://doi-org/10.1111/j.1365-2923.2012.04273.x

Sari, M. (2006). Teacher as a Researcher: Evaluation of Teachers' Perceptions on Scientific Research. Kuram ve Uygulamada Eğitim Bilimleri, 6(3), 880-887. https://web-a-ebscohost- 
com.echo.louisville.edu/ehost/pdfviewer/pdfviewer?vid=116\&sid=1fa44651186d-4fad-933d-3edbd0e5de7d\%40sessionmgr4007

Sinatra, G. M., Brem, S. K., \& Evans, E. M. (2008). Changing minds? Implications of conceptual change for teaching and learning about biological evolution. Evolution: Education and outreach, 1(2), 189. https://doi.org/10.1007/s12052008-0037-8

Sinatra, G. M., \& Broughton, S. H. (2011). Bridging reading comprehension and conceptual change in science education: The promise of refutation text. Reading Research Quarterly, 46(4), 374-393. doi: 10.1002/RRQ.005

Sinatra, G. M., Broughton, S. H., \& Lombardi, D. (2014). Emotions in science education. In R. Pekrun \& L. Linnenbrink-Garcia (Eds.), International handbook of emotions in education.(pp. 415-436). New York, NY: Routledge/Taylor \& Francis Group

Sinatra, G. M., \& Lombardi, D. (2020). Evaluating sources of scientific evidence and claims in the post-truth era may require reappraising plausibility judgments. Educational Psychologist, 1-12. https://doiorg.echo.louisville.edu/10.1080/00461520.2020.1730181

Smithsonian. (2017, June 12). Sending "Learning Styles" Out of Style. Retrieved April 5, 2020, from https://ssec.si.edu/sending-learning-styles-out-style

Sternberg, R.J., Grigorenko, E.L., Ferrari, M., \& Clinkenbeard, P. (1999). A triarchic analysis of an aptitude-treatment interaction. European Journal of Psychological Assessment, 15(1), 1-11. https://psycnet.apa.org/buy/1999-05182-001 
Strike, K. A., \& Posner, G. J. (1992). A revisionist theory of conceptual change. Philosophy of science, cognitive psychology, and educational theory and practice, 176.

Taasoobshirazi, G., Heddy, B., Bailey, M., \& Farley, J. (2016). A multivariate model of conceptual change. Instructional Science, 44(2), 125-145. https://doiorg.echo.louisville.edu/10.1007/s11251-016-9372-2

Tippett, C.D. (2010). Refutation text in science education: A review of two decades of research. International Journal of Science and Mathematics Education, 8(6), 951970. https://doi.org/10.1007/s10763-010-9203-X

Toppo, G. (2019). In learning styles debate, it's instructors vs. psychologists. Retrieved March 30, 2020, from https://www.insidehighered.com/news/2019/01/09/learning-styles-debate-itsinstructors-vs-psychologists

University of Massachusetts Dartmouth. (2019). Tips for Educators on Accommodating Different Learning Styles. Retrieved from https://www.umassd.edu/dss/resources/faculty--staff/how-to-teach-andaccommodate/how-to-accommodate-different-learning-styles/

van Dijk, W., \& Lane, H. B. (2018). The brain and the US education system: Perpetuation of neuromyths. Exceptionality, 7(1). https://doiorg.echo.louisville.edu/10.1080/09362835.2018.1480954

Van Manen, M. (1990). Researching Lived Experience: Human Science for an Action Sensitive Pedagogy.[Albany NY]: State University of New York Press, 1990. Curriculum Inquiry, 24(2), 135-70. 
Vosniadou, S., Carretero, M., \& Schnotz, W. (Eds.). (1999). New perspectives on conceptual change. Pergamon.

Willingham, D. T. (2009). Why don't students like school?: A cognitive scientist answers questions about how the mind works and what it means for the classroom. John Wiley \& Sons.

Willingham, D. T., Hughes, E. M., \& Dobolyi, D. G. (2015). The scientific status of learning styles theories. Teaching of Psychology, 42(3), 266-271.

https://doi.org/10.1177/0098628315589505

Yancovic-Allen, M. (2018). Pre-service elementary teachers' perceptions of conducting and consuming research in their future professional practice. Teachers and Teaching: Theory and Practice, 24(5), 487-499. https://doi.org/10.1080/13540602.2018.1438389

Yough, M., Herron, M., Richards, K. A., \& Ware, J. A. (2015). Working with what is brought: Promoting conceptual change in a course on learning. College Student Journal, 49(3), 355-368.

https://content.ebscohost.com/ContentServer.asp?T=P\&P=AN\&K=109506008\&S $=\mathrm{L} \& \mathrm{D}=\mathrm{a} 9 \mathrm{~h} \&$ EbscoContent $=\mathrm{dGJ}$ MNLr40SeprU4v\%2BbwOLCmsEiep7BSs6m4 Sa\%2BWxWXS\&ContentCustomer=dGJyMPGqs0u0rrVPuePfgeyx44Dt6fIA 


\section{Appendix}

\section{Expository Text}

The learning styles theory refers to the prediction that students learn best when their preferred way of learning (e.g., their "learning style") is matched with the presentation of the material. This theory lacks any scientific evidence to support its claims. In one study, a group of researchers asked participants to identify their learning style. Participants were either "matched" with their preferred modality (e.g., auditory or visual), or they were "mis-matched" and received the material in the modality that was not their preferred learning style. The learning styles theory predicts that the participants who were matched should have learned the material best. Instead, there was no difference in learning between those who were matched vs. those who were not matched. Many others have tested the learning styles theory, and all of them have found the same results: students do not perform better when the learning materials are matched to their learning styles.

\section{Refutation Text}

The learning styles theory refers to the prediction that students learn best when their preferred way of learning (e.g., their "learning style") is matched with the presentation of the material. Contrary to popular belief, this theory lacks any scientific evidence to support its claims. In one study, a group of researchers asked participants to identify their learning style. Participants were either "matched" with their preferred modality (e.g., auditory or visual), or they were "mis-matched" and received the material in the modality 
that was not their preferred learning style. The learning styles theory predicts that the participants who were matched should have learned the material best. Instead, there was no difference in learning between those who were matched vs. those who were not matched. Many others have tested the learning styles theory, and all of them have found the same results. Students do not learn better when the materials are matched to their learning styles. Teachers are correct that their students differ in their prior knowledge, motivation, and interest in a subject. However, the way learning happens is the same for most people. Instead of trying to match material to a learning style, it is better for students to receive material that matches the subject. For example, it benefits students to view a map when learning about geography, regardless of if they prefer visuals.

\section{Indication of Teacher Source}

This text was written by a teacher.

\section{Indication of Researcher Source}

This text was written by a researcher. 
Figure 1

Cognitive Reconstruction of Knowledge Model (Dole \& Sinatra, 1998)

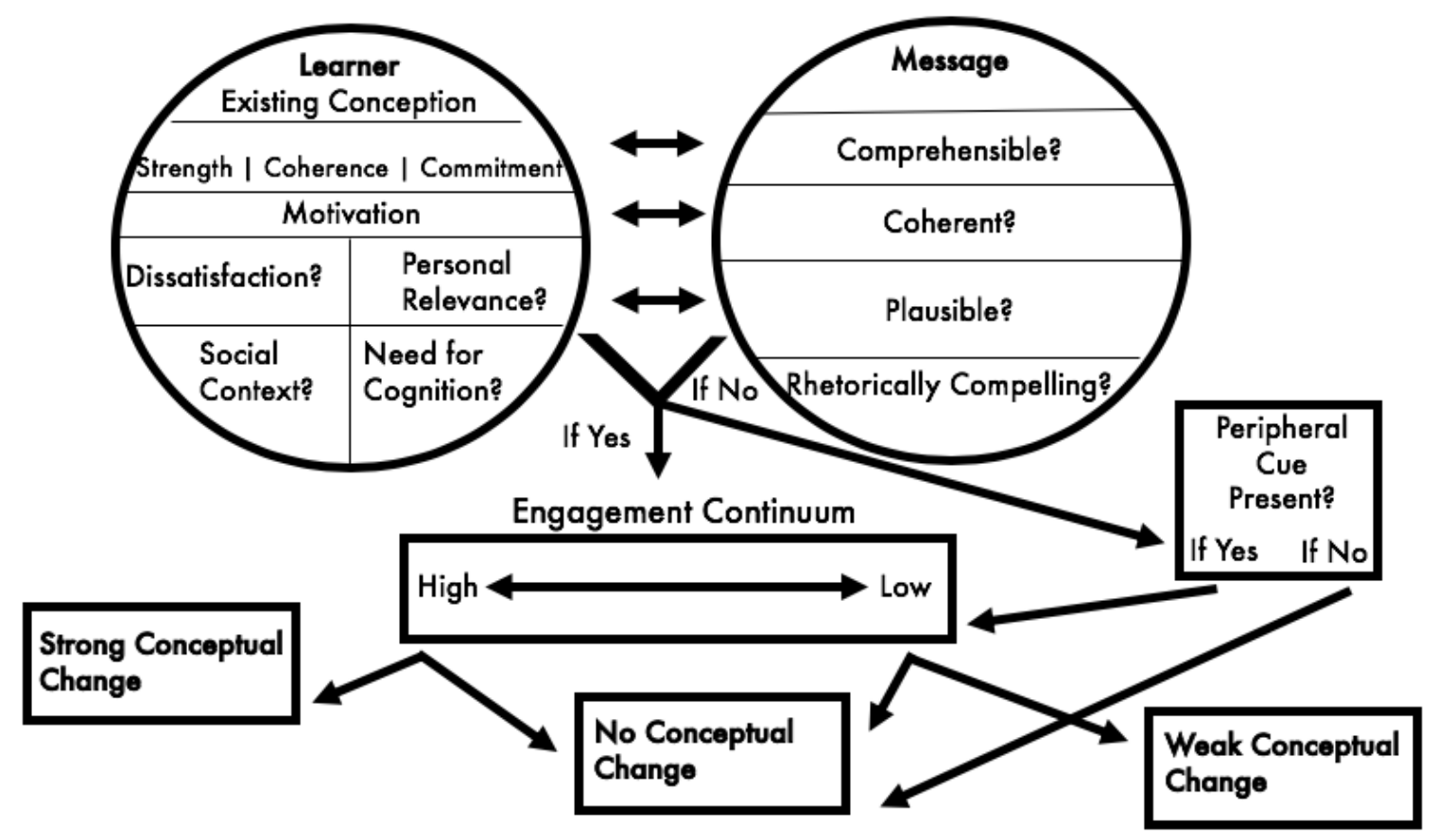


Figure 2

Scatterplots of the Essentialism by Text Type by Source Type Interaction

\section{Text Type}

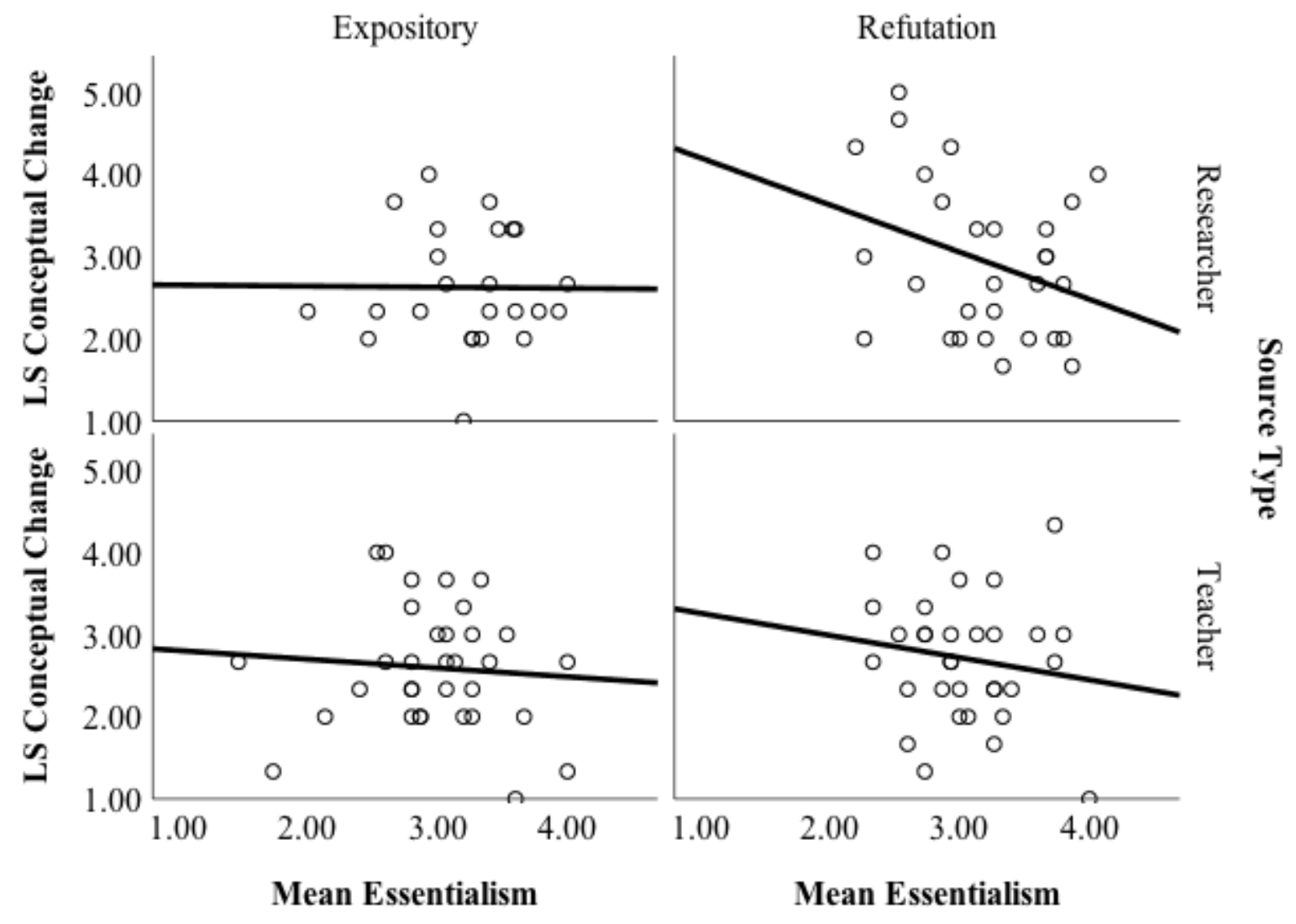


Table 1

Descriptive Statistics for Measures

\begin{tabular}{lcc}
\hline Variable $(N)$ & Mean & Variability Measures \\
\hline Learning Styles Beliefs (118) & $2.7($ Range $=1-5)$ & $.80(S D)$ \\
Source Type (118) & .5 & $45 \%$ Researcher, 55\% Teacher \\
Text Type (118) & .5 & $48 \%$ Expository, 52\% Refutation \\
Essentialism (118) & 3.1 (Range = 1- 6) & $.51(S D)$ \\
Grade Level (118) & .5 & $48 \%$ Elementary, 52\% Secondary \\
\hline
\end{tabular}

Note. Participants responded to Learning Styles Beliefs items on a 5-point Likert scale ranging from 'Strongly Agree' to 'Strongly Disagree'. Participants responded to the Essentialism items on a 6-point Likert scale ranging from 'Strongly Disagree' to 'Strongly Agree'. 
Table 2

Mean and Standard Deviation of Learning Styles Items Scores by Experimental Group

\begin{tabular}{lccc}
\hline & Teacher Source & Researcher Source & Row Statistics \\
\hline Refutation Text & $2.71(0.77), n=32$ & $2.94(0.95), n=29$ & $2.82(0.86), n=61$ \\
Expository Text & $2.60(0.74), n=33$ & $2.62(0.70), n=24$ & $2.61(0.72), n=57$ \\
Column Statistics & $2.65(0.75), n=65$ & $2.80(0.85), n=53$ & \\
\hline
\end{tabular}

Note. Data in the cells represent means and standard deviations (in parentheses). 
Table 3

ANOVA Summary

\begin{tabular}{llllll}
\hline Model & SS & $d f$ & MS & $F$ & $p$ \\
\hline Regression & 4.00 & 5 & 0.80 & 1.26 & .28 \\
Residual & 71.25 & 112 & 0.64 & & \\
Total & 75.25 & 117 & & & \\
\hline
\end{tabular}


Table 4

Multiple Regression Results

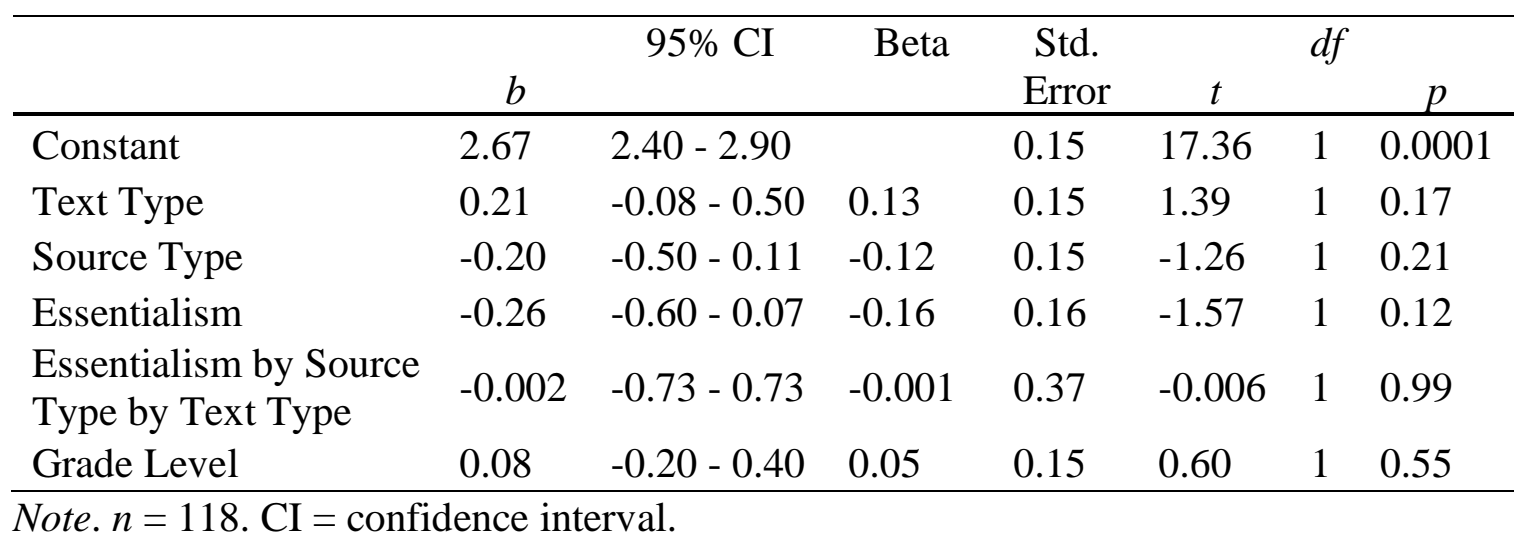

Note. $n=118 . \mathrm{CI}=$ confidence interval. 
Table 5

Coding Frequency - Learning Styles Endorsers

\begin{tabular}{|c|c|c|c|}
\hline Question & Code & $\begin{array}{c}\text { Times } \\
\text { Mentioned } \\
\end{array}$ & Sample Quote \\
\hline \multirow{4}{*}{$\begin{array}{l}\text { To what extent } \\
\text { did reading the } \\
\text { text affect your } \\
\text { belief about } \\
\text { learning } \\
\text { styles? }\end{array}$} & None & 22 & "No change in my opinions" \\
\hline & Some & 43 & "To some extent" \\
\hline & $\begin{array}{l}\text { Changed } \\
\text { Mind }\end{array}$ & 8 & $\begin{array}{l}\text { "My beliefs have now changed about } \\
\text { learning styles." }\end{array}$ \\
\hline & $\begin{array}{l}\text { Confirmed } \\
\text { Beliefs }\end{array}$ & 8 & $\begin{array}{l}\text { "It confirmed what I thought/had heard } \\
\text { that learning styles aren't actually } \\
\text { useful" }\end{array}$ \\
\hline \multirow{5}{*}{$\begin{array}{l}\text { Describe your } \\
\text { reactions to the } \\
\text { claims about } \\
\text { learning styles } \\
\text { made in the } \\
\text { texts. }\end{array}$} & Criticism & 16 & $\begin{array}{l}\text { "I have some questions about the } \\
\text { validity of the study, how many people } \\
\text { were used, and whether there are other } \\
\text { conflicting studies on this matter." }\end{array}$ \\
\hline & Surprise & 20 & $\begin{array}{l}\text { "I was surprised that the preferred } \\
\text { learning style did not improve or } \\
\text { decrease academic performance" }\end{array}$ \\
\hline & Disagreement & 15 & "I did not believe the claims." \\
\hline & Agreement & 5 & "I wholeheartedly agree!" \\
\hline & No Reaction & 12 & $\begin{array}{l}\text { "For me, it doesn't make a huge } \\
\text { difference" }\end{array}$ \\
\hline \multirow{4}{*}{$\begin{array}{l}\text { In what ways } \\
\text { did the authors } \\
\text { expertise affect } \\
\text { your } \\
\text { perceptions } \\
\text { about the } \\
\text { information (if } \\
\text { at all)? }\end{array}$} & None & 33 & "Not at all. I go more with experience" \\
\hline & Impacted & 18 & $\begin{array}{l}\text { "My perceptions changed because of the } \\
\text { author's expertise." }\end{array}$ \\
\hline & $\begin{array}{l}\text { Partially } \\
\text { Impacted }\end{array}$ & 10 & $\begin{array}{l}\text { "Somewhat only because it was a } \\
\text { study." }\end{array}$ \\
\hline & $\begin{array}{l}\text { Questioning } \\
\text { Expertise }\end{array}$ & 7 & $\begin{array}{l}\text { "What expertise? We were told that is } \\
\text { was a 'researcher'. That could be } \\
\text { anyone?" }\end{array}$ \\
\hline
\end{tabular}

Note. Frequency of codes may not reflect the number of respondents, as some responses

did not fall under any dominant codes, and some responses were more complex, and were divided into statements with more than one code. 
Table 6

Coding Frequency - Learning Styles Non-Endorsers

\begin{tabular}{|c|c|c|c|}
\hline Question & Code & $\begin{array}{c}\text { Times } \\
\text { Mentioned }\end{array}$ & Sample Quote \\
\hline \multirow{3}{*}{$\begin{array}{l}\text { Describe your } \\
\text { current beliefs } \\
\text { about learning } \\
\text { styles. }\end{array}$} & Evidence & 10 & "There is no empirical evidence for this." \\
\hline & Preferences & 11 & $\begin{array}{l}\text { "People can have a preferred way of learning } \\
\text { but it is not the only way they can learn." }\end{array}$ \\
\hline & Rationale & 10 & $\begin{array}{l}\text { "Teaching geography in an auditory style } \\
\text { doesn't make sense. This is one example where } \\
\text { the content dictates the best strategy: using a } \\
\text { map." }\end{array}$ \\
\hline \multirow{3}{*}{$\begin{array}{l}\text { If applicable, } \\
\text { describe how } \\
\text { your beliefs } \\
\text { about learning } \\
\text { styles have ever } \\
\text { been different } \\
\text { than they are } \\
\text { currently? }\end{array}$} & $\begin{array}{l}\text { Taught during } \\
\text { Degree/Early } \\
\text { Career }\end{array}$ & 9 & $\begin{array}{l}\text { "In college I was taught that each student had a } \\
\text { preferred learning style. This is still referenced } \\
\text { today at conferences and in classes." }\end{array}$ \\
\hline & Never Believed & 4 & "I never loved the idea of learning styles." \\
\hline & Research Debunked & 7 & $\begin{array}{l}\text { "Before hearing research regarding this, I } \\
\text { believed in the idea of each of us having a } \\
\text { learning style." }\end{array}$ \\
\hline \multirow{3}{*}{$\begin{array}{l}\text { Describe the } \\
\text { evidence against } \\
\text { learning styles } \\
\text { that you find } \\
\text { most convincing } \\
\text { and why. }\end{array}$} & Research & 9 & $\begin{array}{l}\text { "The various published studies that show that } \\
\text { "learning styles" is a myth." }\end{array}$ \\
\hline & $\begin{array}{c}\text { Teaching } \\
\text { Experience }\end{array}$ & 5 & $\begin{array}{l}\text { "Anecdotal evidence based on my experiences } \\
\text { with hundreds of students. " }\end{array}$ \\
\hline & Logic/Reasoning & 6 & $\begin{array}{l}\text { When students are taught in different } \\
\text { modalities they benefit - all students benefit } \\
\text { from dual coding - not just the ones that } \\
\text { "prefer" one style to another. }\end{array}$ \\
\hline \multirow{4}{*}{$\begin{array}{l}\text { Why do you } \\
\text { believe } \\
\text { educators so } \\
\text { often hold this } \\
\text { belief? }\end{array}$} & Popular & 12 & $\begin{array}{l}\text { "Because we are taught this garbage in our PD } \\
\text { days and in our education classes!" }\end{array}$ \\
\hline & $\begin{array}{c}\text { Student } \\
\text { Engagement }\end{array}$ & 5 & $\begin{array}{l}\text { "Of course kids WANT to do hands } \\
\text { on/kinesthetic activity, this doesn't mean they } \\
\text { are doing any valuable learning necessary or } \\
\text { learning content on a deeper level." }\end{array}$ \\
\hline & Easy/Sounds Good & 6 & $\begin{array}{l}\text { "It's an easy belief to cultivate and it seems } \\
\text { obvious to some extent." }\end{array}$ \\
\hline & $\begin{array}{l}\text { Not Engaging in } \\
\text { Research }\end{array}$ & 4 & $\begin{array}{l}\text { "Educators should think critically and } \\
\text { thoughtfully reflect about pedagogical fads" }\end{array}$ \\
\hline
\end{tabular}

Note. Frequency of codes may not reflect the number of respondents, as some responses

did not fall under any dominant codes, and some responses were more complex, and were divided into statements with more than one code. 
Table 7

Coding Process Examples

\begin{tabular}{|c|c|c|}
\hline First Cycle Codes & Second Cycle Codes/Process & Broader Theme \\
\hline $\begin{array}{l}\text { Evidence, Research } \\
\text { Debunked, Research, Not } \\
\text { Engaging in Research }\end{array}$ & $\begin{array}{l}\text { believed as early teacher --> } \\
\text { research }+ \text { observations --> } \\
\text { don't believe }\end{array}$ & $\begin{array}{l}\text { Exposure to Research Largely } \\
\text { Informs Teachers' } \\
\text { Conceptions. }\end{array}$ \\
\hline $\begin{array}{l}\text { None, Some, Changed Mind, } \\
\text { Confirmed Beliefs }\end{array}$ & $\begin{array}{l}\text { Exp vs. Ref text comparisons, } \\
\text { Teacher vs. Researchers } \\
\text { source comparisons, } \\
\text { Essentialism comparisons }\end{array}$ & $\begin{array}{l}\text { More than None but Less than } \\
\text { All, I Knew It All Along, } \\
\text { Group and Individual } \\
\text { Differences Didn't (Usually) } \\
\text { Matter }\end{array}$ \\
\hline $\begin{array}{l}\text { Criticism of the Study, } \\
\text { Disagreement, None }\end{array}$ & $\begin{array}{l}\text { Classroom expertise over } \\
\text { research, Anecdotal } \\
\text { experience, Dismissal of } \\
\text { results }\end{array}$ & Personal Experience is King \\
\hline
\end{tabular}

Note. This table includes examples of the coding process from first cycle codes to second cycle codes and coding processes, to broader themes. 


\section{CURRICULUM VITAE}

Allison Fowler

University of Louisville

College of Education \& Human Development

Educational Psychology, Measurement, and Evaluation

Louisville, KY, 40292

Phone: 502-594-1513

Email: apwill06@louisville.edu

\section{EDUCATION}

University of Louisville | Educational Psychology, 2020

Measurement, \& Evaluation | Doctoral Candidate

University of Kentucky | Elementary Education, January 2013 - May 2016

Magna Cum Laude | B.A

August 2016 - May

\section{PUBLICATIONS}

\section{Peer Reviewed Journal Articles}

Storlie, C. A., Woo, H., Fink, M., \& Fowler, A. (2019). A Content Analysis of the Domains of Advocacy Competencies in Select Counseling Journals: 2004-2016. Journal of Counselor Leadership and Advocacy, 1-13.

Valentine, J.C., Leach, S.M., Fowler, A., Stodja, D.K., Macdonald, G. (2019). Families and Schools Together (FAST) for improving outcomes for children and their families. Cochran Database of Systematic Reviews 2019. Issue 7. Art. No.: CD012760

Snyder K. E., Pittard C. M., Fowler A., \& Watson C. T. (2020). "Epic-Genetics": An exploration of preservice helping professionals' (mis)understanding of epigenetic influences on human development. Teaching \& Learning Inquiry, 8(1), 122-137. https://doi.org/10.20343/teachlearninqu.8.1.9 


\section{Journal Articles Under Review}

Woo, H., Fowler, A., Jang, Y., \& Kim, J. (under review). A content analysis of articles on multidisciplinary collaboration for K-12 Students: American Counseling Association (ACA) journals over the last 15 years. British Journal of Guidance \& Counselling.

Fowler, A., Snyder K.E., \& Alagaraja, M. (under review). Looking in the mirror: A phenomenological exploration of the researcher perspective in underachievement.

\section{Non-Refereed Publications}

Fowler, A., (2018). Giftedness, grants, and the give-and-go: an interview with Dr. Joyce VanTassel-Baska. AERA ROGCT SIG Fall Newsletter.

Fowler, A., Adelson, J. L., \& Snyder, K. E. (December, 2018). Executive summary of Project RAP evaluation data, December 2018. Report submitted to Kentucky Department of Education and to Institute of Education Sciences.

Fowler, A., Adelson, J. L., \& Snyder, K. E. (July, 2019). Executive summary of Project RAP evaluation data, July 2019. Report submitted to Kentucky Department of Education and to Institute of Education Sciences.

\section{Edited Book Chapters}

Fowler, A., Snyder, K.E. (In press). Critical issues and practices in gifted education: Thinking and learning styles. Prufrock Press.

\section{Refereed Conference Presentations}

Fowler, A., (March, 2018) Realigning measurement with conceptualization in underachievement. Presented at Spring Research Conference, Louisville, KY.

Fowler, A., (November, 2018) Synthesizing javits: what has 120 million dollars produced in 30 years? Poster presented at National Association for Gifted Children Graduate Student Research Gala, Minneapolis, MN. 
Fowler, A., (March, 2019) Understanding underachievement: A phenomenological approach. Presented at Spring Research Conference, Lexington, KY.

Fowler, A., (March, 2019) “Epic-Genetics”: An exploration of pre-service helping professionals' (mis)understanding of epigenetic influences on human development. Presented at Graduate Student Research Conference, Louisville, $\mathrm{KY}$.

Fowler, A., (November, 2019) The researcher in the mirror: A phenomenological exploration of the researcher perspective in underachievement. Presented at National Association for Gifted Children Graduate Student Research Gala, Albuquerque, NM.

Fowler, A., (April, 2020) The researcher in the mirror: A phenomenological exploration of the researcher perspective in underachievement. Presented at American Educational Research Association Annual Conference, San Francisco, CA.

\section{RESEARCH AND RELEVANT EXPERIENCE}

Snyder Motivation and Achievement Research Team (SMART)

2017-2019

Lab Manager

Guild for Engineering Achievement, Retention, and Success (GEARS)

Reaching Academic Potential Testing, Organization, and Research Specialists (RAPTORS) Team Leader

Research Assistant to Jefferson County Public Schools 2016, 17

Advance Program Director for Javits Grant

Internship in Data Management Department 2018 Jefferson County Public Schools

\section{TEACHING EXPERIENCE}

Instructor | Learning \& Human Development, July 2019- December 2019 ECPY 507/607

Instructor | Building Learning Communities, July 2019- December 2019 EDTP 328 
Co-Instructor | Public Schools in America,

January 2019- May 2019

EDTP 506

Instructor | Human Development \& Learning,

August 2017-December 2018

EDTP 107

Teaching Assistant | Learning Theories \& Systems,

January 2018 - May 2018

ECPY 611

Teaching Assistant | Human Development,

January 2017- May 2017

ECPY 605

Student Teaching | Fayette County Public Schools

January 2016 - May 2016

\section{PEER REVIEWING}

Scholarship of Teaching and Learning in Psychology

Journal of Educational Psychology

\section{AWARDS}

Graduate Student Travel Award

2020

(\$750) Award to present at AERA conference

College of Education and Human Development March

2019

Student of the Month

University of Louisville Faculty Favorite

2018

19

Student-nominated teaching award

Graduate Student Council Travel Scholarship

(\$350) Travel Award to attend NAGC conference

Integrating Women Leaders Foundation Conference Scholarship

2017

(\$299) Award to attend IWL conference

\section{INVITED TALKS}

Qualitative Research Methods

Guest Lecture at Hanover College

A Gentle Introduction to Multilevel Modeling 
Graduate Teaching Assistants Academy

Talk on Learning Theory

\section{PROFESSIONAL AFFILIATIONS}

The Prichard Committee for Academic Excellence

2019-present

Groundswell Initiative

American Educational Research Association

2017-present

AERA SIG- Motivation in Education

AERA SIG- Research on Giftedness, Creativity, and Talent

American Psychological Association

2017-present

Division 15- Educational Psychology

National Association for Gifted Children

2017-present 